\title{
The Glarus thrust: excursion guide and report of a field trip of the Swiss Tectonic Studies Group (Swiss Geological Society, 14.-16. 09.2006)
}

\author{
Marco Herwegh ${ }^{1, *}$, Jean-Pierre Hürzeler ${ }^{2}$, O. Adrian Pfiffner ${ }^{1}$, Stefan M. Schmid ${ }^{2}$, \\ RAINER ABART $^{3} \&$ ANDREAS EBERT ${ }^{1}$
}

Key words: Helvetics, Glarus thrust, deformation mechanism, mylonite, brittle deformation, geochemical alteration, fluid pathway

\section{PARTICIPANTS}

\author{
Ansorge Jörg (ETHZ) \\ den Brok Bas (EAWAG-EMPA) \\ Dèzes Pierre (SANW) \\ Gonzalez Laura (University of Bern) \\ Herwegh Marco (University of Bern) \\ Hürzeler Jean-Pierre (University of Basel) \\ Imper David (GeoPark) \\ Mancktelow Neil (ETHZ) \\ Mullis Josef (University of Basel)
}

\begin{abstract}
This excursion guide results form a field trip to the Glarus nappe complex organized by the Swiss Tectonic Studies Group in 2006. The aim of the excursion was to discuss old and recent concepts related to the evolution of the Glarus thrust. The major aspects were (i) the interplay between deformation, fluid flow and geochemical alteration, (ii) episodic versus continuous deformation
\end{abstract}

\author{
Nyffenegger Franziska (Fachhochschule Burgdorf, University of Bern) \\ Pfiffner Adrian (University of Bern) \\ Schreurs Guido (University of Bern) \\ Schmalholz Stefan (ETHZ) \\ Schmid Stefan (University of Basel) \\ Wiederkehr Michael (University of Basel) \\ Wilson Christopher (Melbourne University) \\ Wilson Lilian (Melbourne University)
}

and fluid flow, and (iii) the link between large-scale structures, microstructures, and geochemical aspects. Despite 150 years of research in the Glarus nappe complex and the new results discussed during the excursion, there exist controversies that still are unsolved.

\section{Introduction}

The Oligo-Miocene-age Glarus thrust in the Alps of eastern Switzerland separates the Glarus nappe complex from its footwall. Permian red beds (Verrucano) at the base of the Helvetic nappes are seen to discordantly overlie a series of complexly folded and thrusted units. The latter, referred to as Infrahelvetic complex (Pfiffner 1977; Milnes and Pfiffner 1977), predominantly consists of Mesozoic limestones ("Parautochthonous") overlying crystalline basement rocks in the south and of a series of mainly Cenozoic "Flysch" units in the north. Since some of the units in the Infrahelvetic complex are of more southerly origin than the Helvetic nappes (Trümpy 1969), we are confronted with a classical example of out-of-sequence thrusting that postdates earlier events. From a geodynamical point of view, however, the opinions of the participants vary all the way from those who propose out-of-sequence thrusting to represent a completely separate late-stage orogenic event (Bas den Brok and co-workers; Gasser \& den Brok this volume; unpublished work by Jagoutz 2000, Giger 2003, Gasser 2006) to those who propose a continuous and smooth transition from folding to discrete thrusting (i.e. Pfiffner 1996). Due to its spec-

${ }^{1}$ Institute of Geological Sciences, University of Bern, Baltzerstr. 1 \& 3, CH-3012 Bern.

${ }^{2}$ Institute of Geology and Paleontology, Basel University, Bernoullistrasse 32, CH-4056 Basel.

${ }^{3}$ Institute of Geological Sciences, Freie Universität Berlin, Malteserstr. 74-100, D-12249 Berlin.

*Corresponding Author: Marco Herwegh, Institute of Geological Sciences, University of Bern, Baltzerstr. 1 \& 3, CH-3012 Bern.

E-mail: herwegh@geo.unibe.ch 
tacular appearance, and in view of the total displacement of at least 30-40 km (e.g. Schmid 1975), the Glarus thrust is one of the most prominent large-scale low-angle thrusts in the Alps, and has been well studied during some 150 years of research. It is for these reasons that the area between Flims and Walensee has been nominated to become inscribed into the list of the UNESCO world natural heritage sites in 2007.

As will be outlined in the following, research addressing the Glarus thrust has been episodic. This is because such research was closely linked to advances in analytical techniques and methodology that were applied to the study of the Glarus nappe complex. Research on the Glarus thrust started in the second half of the $19^{\text {th }}$ century with a dispute about its existence. While Heim (1878) interpreted this structure as due to the combination of two huge overturned folds facing each other ('Glarus double fold'), Escher von der Linth (1846; see Heim 1929 and Bertrand 1884) promoted its interpretation in terms of a single overthrust. After this structure was finally accepted as a thrust (see also Trümpy et al. 1991), research in the first part of the $20^{\text {th }}$ century was dominated by detailed mapping and unraveling of the stratigraphy, as well as by analyses of the large-scale structures within both the footwall and hanging wall of the Glarus thrust (e.g. Heim 1921; Oberholzer 1933; Helbling 1948; Staub 1954). New analytical techniques in the field of structural geology induced a wave of structural investigations in the 1970's (e.g. Bürgisser and Felder 1974; Schmid 1975; Milnes and Pfiffner 1977; Pfiffner 1978; Pfiffner 1980). During this time, Pfiffner (1977) unraveled the deformation sequence involving stages of initial imbrication of Infrahelvetic units and culminating in the final emplacement of the Glarus nappe. Simultaneously, the first interpretations in terms of the physical state and the mechanics of the Glarus thrust were developed (Hsü 1969; Schmid 1975; Briegel and Goetze 1978). Particularly the advances in rock mechanics and in understanding of the relationship between microstructure, deformation process and rheology motivated Schmid et al. (1977) to perform rock deformation experiments on fine grained limestone in order to compare the natural and experimental microfabrics (Schmid 1982). Based on this comparison, viscous grain boundary sliding ("superplasticity") was postulated as the major deformation mechanism active during flow of the Lochsite limestone, a calc-tectonite representing a thin veneer of low-viscosity material that accommodated displacement along the Glarus thrust. Later microstructural analyses, combined with TEM investigations, by Pfiffner (1982) confirmed this interpretation for the northern parts of the Glarus thrust, while for southern areas the microstructures were more indicative of a predominance of dislocation creep. The following research period was dominated by studies on low-grade metamorphism (e.g. Frey 1988; Groshong 1988; Rahn et al. 1994; Rahn et al. 1995; Mullis et al. 2002), geochronology and geochemistry (Hunziker et al. 1986). Particularly illite crystallinity, vitrinite reflectance, fluid inclusions, fission track analysis and stable isotope mass spectrometry were the major research tools used. Martin Burkhard and his collaborators were among the first to use the stable isotope composition in the calc-tectonites of the Glarus thrust to investigate the effect of fluids on deformation (Burkhard et al. 1992), a research direction followed in many later studies (e.g. Badertscher and Burkhard 2000; Ring et al. 2001; Badertscher et al. 2002a \& b; Abart et al. 2002). With this approach, Martin Burkhard made an important breakthrough to better understand the origin and role of fluids during activity of the Glarus thrust and opened a research field that is still very active to the present day. Recently, new developments in quantitative microfabric analysis (e.g. electron backscatter diffraction, digital image processing and analysis) provoked a series of new microstructural and geochemical investigations (Ebert 2006, Ebert et al. 2007b, Abart et al. 2002, Hürzeler and Abart 2008), which tried to link small-scale deformation and geochemical processes with the large-scale evolution of the Glarus thrust.

Given all these data obtained with new methods, the major goal of this excursion was to present new results and to discuss them in the context of ideas and concepts surrounding this famous thrust. This excursion guide presents the individual stops visited (Fig. 1), describes the characteristic observations that can be made at these locations and discusses possible inferences. It became clear to the participants that many aspects of this famous thrust still remain rather enigmatic and authors and participants did not always agree. This guide highlights some of the debates amongst participants, which hopefully will stimulate further research.

We would like to dedicate this paper to Martin Burkhard in memory of his outstanding contributions to the Swiss geology and to the Glarus thrust in particular.

\section{September $14^{\text {th }} 2006$}

\section{Route}

Drive from Ziegelbrücke to the Lochsite (Schwanden, GL), then to Mels (SG), Flims (GR, $1100 \mathrm{~m}$ ) and Laax (GR), access road to Camona da Nagens. Walk from Camona da Nagens (2127 m) to Segneshütte (2102 m), Plaun Segnes Sut and back to Segneshütte (see Fig. 1).

\section{Stop 1: Lochsite (Coord. 725'875/206'425)}

Neil Mancktelow, president of the Swiss Tectonic Studies Group, welcomed all participants and recalled the tragic death of Prof. Martin Burkhard induced by an accident during fieldwork in August 2006. Martin was a very active member of the Swiss Tectonic Studies Group, always enthusiastic and a very motivating teacher and colleague, investing his full energy in his scientific work, for which we admire him so much. Because of his fundamental contributions addressing the fluid history of the Glarus overthrust, based on stable isotope analyses (e.g. Burkhard et al. 1992; Badertscher et al. 2002a \& b), it had been planned that he would act as one of the principal leaders of this excursion, a task which was so sadly and abruptly terminated. In memory of Martin, the excursion started with a minute of

324 M. Herwegh et al. 


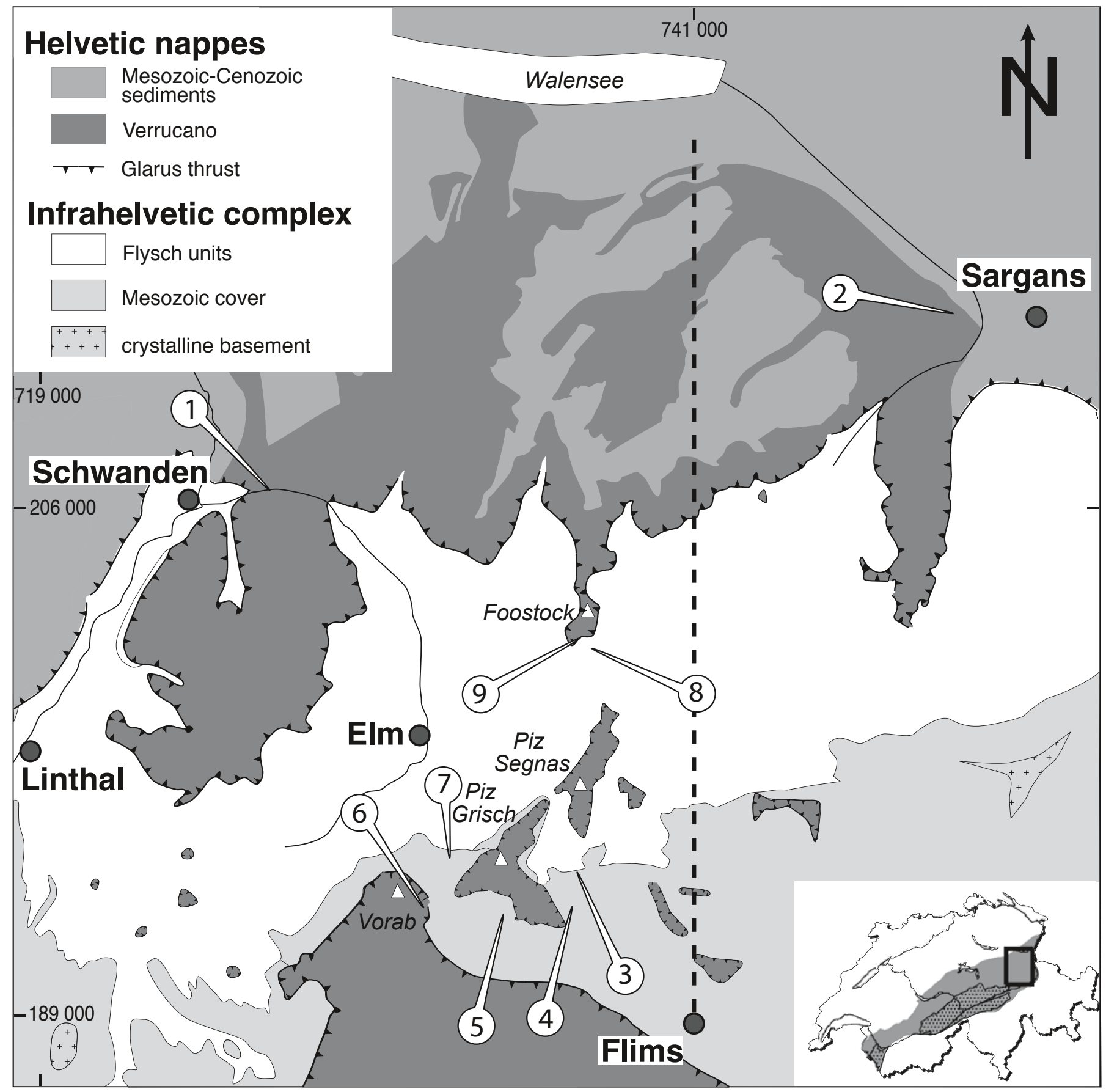

Fig. 1. Overview map of the tectonic framework in the Helvetic units of eastern Switzerland, with the trace of the Glarus thrust indicated. Numbers correspond to the different stops visited during the STSG excursion 2006. Stippled line shows the trace of the tectonic profile in Fig. 11.

silence. His ideas and concepts were presented and intensely discussed, keeping Martin's spirit present in the memory of all of us during the entire field trip.

The famous Lochsite locality is part of the GeoPark (www. geopark.ch) and is one of the northernmost outcrops of the Glarus overthrust. Here, the Verrucano (Permian) is emplaced onto North Helvetic Flysch of Cenozoic-age (Figs. 1, 2). The actual thrust contact between the two rock types is located in a zone of intensely deformed veined calcite, referred to in the literature as Lochsitekalk (limestone) or Lochsite calcmylonite (e.g. Heim 1921; Schmid 1975; Schmid 1981; Pfiffner 1982; Badertscher and Burkhard 2000). Undoubtedly this fault rock has accommodated high shear strains during a long lasting deformation history. Straining involved viscous (crystal 


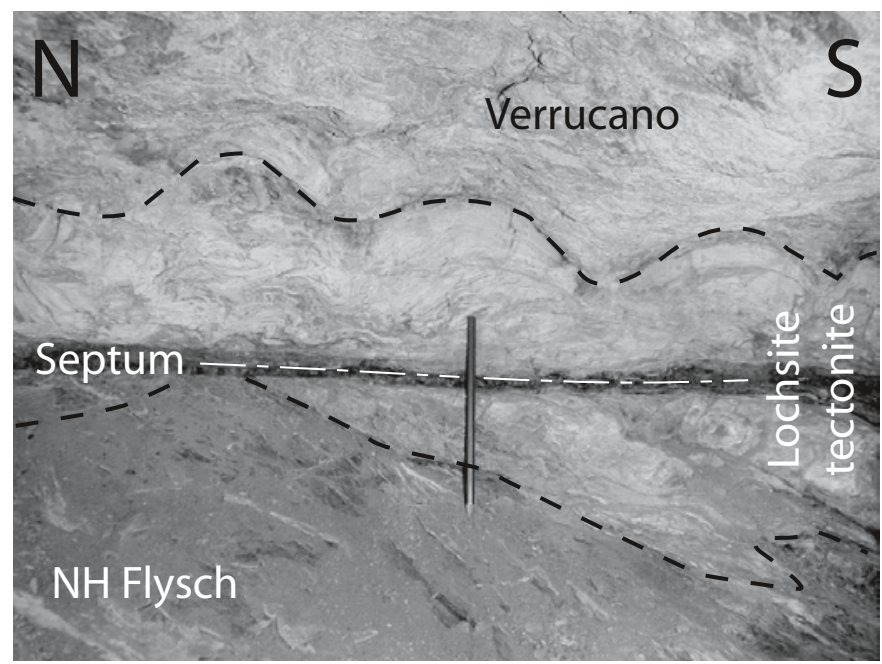

Fig. 2. Stop 1 (Lochsite). Glarus thrust characterized by the Lochsite tectonite located between footwall North Helvetic Flysch and hanging wall Verrucano. At this location, the tectonite consists of intensely folded calcite veins, dissected by a planar fracture plane, the so-called septum comprising a greenish fault gouge.

plasticity, grain-size sensitive creep etc.) but at the same time also cataclastic deformation processes in the presence of fluids. It was agreed that these processes occurred simultaneously. It remained a matter of debate, however, as to what the relative contributions of the different deformation mechanisms toward the total strain actually were and whether and how these relative contributions may have changed over time. Since the term 'mylonite' already implies a genetic interpretation in the light of viscous deformation mechanisms (Schmid \& Handy 1991), S. Schmid proposed that Lochsite calc-mylonite ought to be replaced by the more neutral term 'Lochsite tectonite'.

The contact of the Lochsite tectonite to the Verrucano in the hanging wall is defined by a wavy surface, above which the Verrucano is deformed only within a narrow zone, two to three meters wide (Fig. 2). At the base of the Verrucano, fluids induced chemical alteration and mineral reactions (Abart and Ramseyer 2002). The impressive change from the typically reddish colors towards the green colors seen along this thrust contact is a direct manifestation of the reduction of ferric to ferrous iron. For example, new chlorites grew, feldspar decomposed to sericite and the bulk and isotope chemistry changed (Fig. 3). Whereas sodium concentrations show a pronounced decrease in the lowermost meter of the Verrucano, the $\mathrm{Al}_{2} \mathrm{O}_{3}$ and $\mathrm{K}_{2} \mathrm{O}$ concentrations increase in a complementary manner. This reflects dissolution of albite-rich plagioclase in places where the sodium was removed supposedly via a fluid phase, whereas alumina and potassium were immobilized by sericite formation. Within this alteration zone, oxygen isotope compositions of quartz (not shown in Figure 3) and calcite show a systematic downward increase in $\delta^{18} \mathrm{O}$, which for calcite is from $16 \%$ to $23 \%$ o towards the thrust contact (Fig. 3). Abart et al.

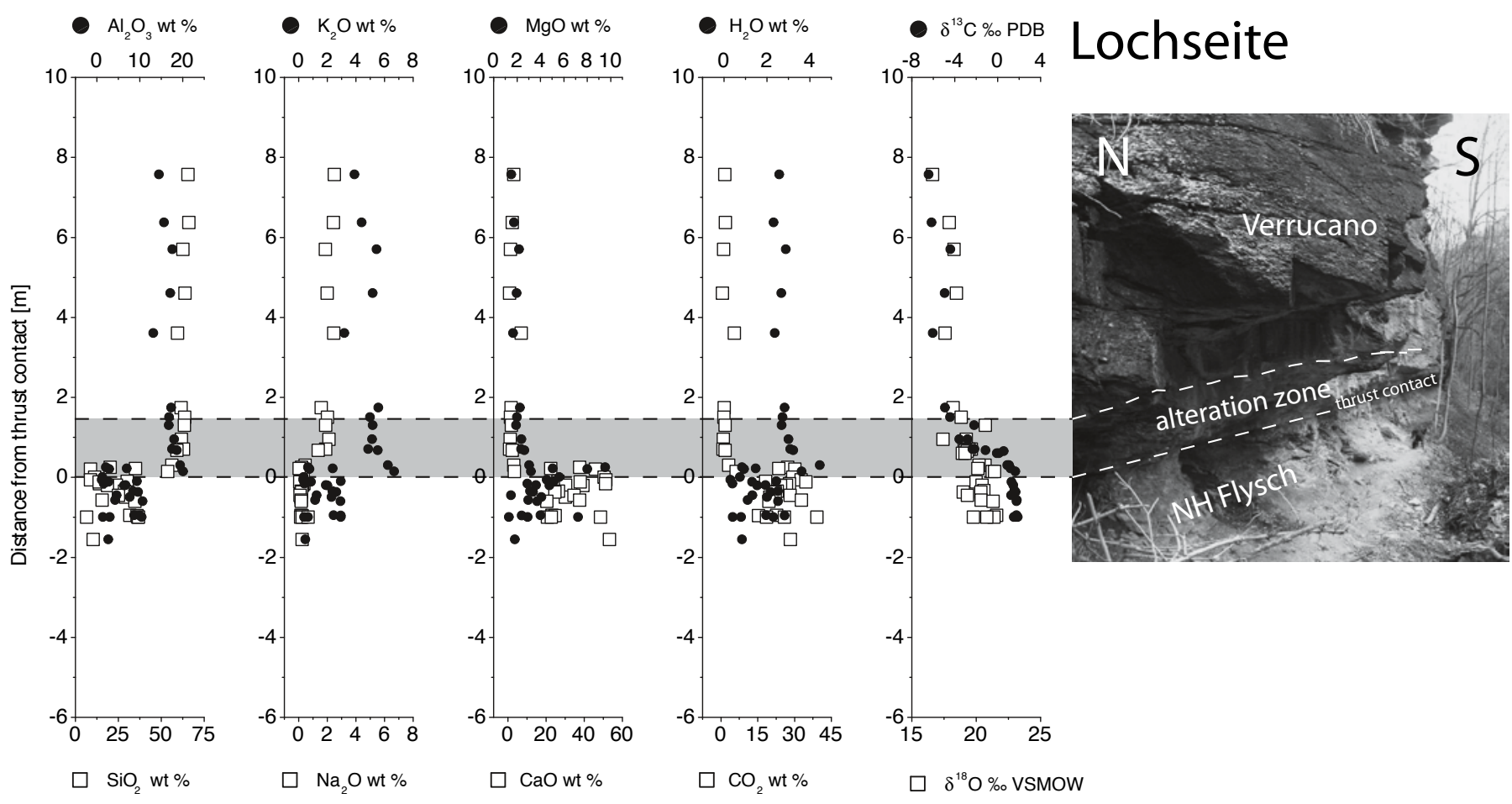

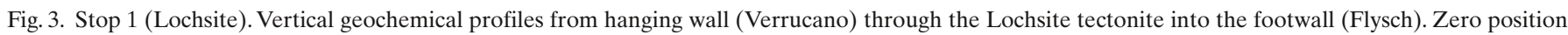
marks the Verrucano contact followed by its basal alteration zone (grey shading). Data from Abart et al. (2002).

326 M. Herwegh et al. 
(2002) interpreted this as evidence for upwards-directed fluid flow across the thrust. The correlation between deformation intensity and extent of isotope alteration of oxygen in quartz suggest that dissolution and re-precipitation of quartz, associated with deformation, was the main mechanism of quartz-fluid oxygen isotopic exchange (Abart and Ramseyer, 2002; Abart et al. 2002). In the red Verrucano above the green alteration zone, the thrust-related deformation decreases rapidly and the rocks only show a weak foliation away from the thrust contact. The latter is interpreted to be older than the thrust-related structures and pertains to the Calanda phase (Milnes and Pfiffner 1977; Pfiffner 1977; Siddans 1979).

In contrast to the undulating upper interface of the Lochsite tectonite, cusps and lobes characterize its lower interface with the footwall, with cusps of slate of the North-Helvetic Flysch penetrating into the Lochsite tectonite. The geometry observed at Lochsite, i.e. a folded lower part of the Lochsite tectonite, which is dissected by planar thrust-parallel fabrics closer to the Verrucano contact and crosscut by a discrete septum (Fig. 2), is found in most outcrops all along the entire Glarus thrust (e.g. see also stops 5 and 6). Cuspate-lobate geometries generally form at the interface of two rock types with contrasting mechanical properties and it is the mechanically weaker material (the flysch slates), which forces the cusps penetrating into the stronger one (the Lochsite tectonite). Paradoxically, this would imply that the flysch slate was the weaker material, at least during the formation of these cusps and lobes, while the thrust-related, extremely high shear strains have been accommodated in the 'stronger' Lochsite tectonite.

Several explanations for solving this apparent paradox were proposed. (a) The cuspate-lobate geometry could be the result of the strong fabric anisotropy in the flysch slates, which is rich in sheet silicates, leading to anisotropy-driven folding of the interface. If this was the case, the observed geometry may not necessarily reflect a lower strength of the flysch slates in terms of the accommodation of thrust-parallel simple shear. (b) At the time of cusp and lobe formation, the active and mechanically weak part of the shear zone may have been closer to the Verrucano, allowing the lower part of the tectonite, which was active at an earlier time, to form cusps and lobes during ongoing simple shearing in the higher portions of the Lochsite tectonite. (c) Conversely, according to Bas den Brok, cusp-lobe formation may predate late-stage thrusting in the upper portions of the Lochsite tectonite, with late-stage thrusting subsequently crosscutting cuspate-lobate folding structures. In this scenario, folding and thrusting events would be separated by time gaps and would not represent a progressive deformation during one single event of overthrusting. As outlined below, these three different concepts also have important consequences for the interpretation of the evolution of the large-scale tectonic framework of the entire Glarus nappe complex.

However, one feature is clearly seen to post-date all the other structures. A straight fault, referred to as the 'septum' (Fig. 2; Heim 1921), is observed in the central part of the Lochsite tectonite. It crosscuts all other structures, such as schistosity and folded veins. On closer inspection, this septum consists of a dark fault gouge of 0.1 to $5 \mathrm{~cm}$ thickness. However, this gouge is specific for the Lochsite locality only (Fig. 2). Furthermore, the septum does not appear to consist of a single fault but rather displays a sequence of brittle faults, linked to each other in a stepwise manner.

Stop 2: Castels (Geoweg Mels, Coord. 749'925/212'825)

During a 10 minute walk, David Imper, president of GeoPark, led the excursion to Castels hill, a Verrucano drumlin in the Seez valley that is part of the Geoweg Mels (Fig. 1). On the way to Castels, we passed a former millstone quarry, where leftovers of unfinished millstones, which were in preparation at the time of last quarry activity, can still be seen. Due to the excellent abrasion behavior, the industrial demand for Verrucano was quite high at the beginning of the $19^{\text {th }}$ century, and the hand-chiseled millstones were exported to destinations all over Europe.

On Castels hill, a display of various boulders collected nearby gives an excellent overview of the different rock types present in the area. In addition, Castels is a viewpoint for regarding details of the internal large-scale structure of the Helvetic nappes. In a view to the north, the Mid- and Late Jurassic strata can be seen shortened by folding and imbrication. The large-scale classical ramp fold of the Tschuggen marks the transition from the folding seen in the Gonzen fold (former iron mine) in the SE to imbrication in the NW (Trümpy 1969, his plate 1). The structures are outlined by massive Late Jurassic limestones (Quinten Formation). These imbricates form a classical horse-structure, underneath a roof thrust (Säntis Thrust) formed by marly and slaty rock types that acted as lubricants during imbrication (Pfiffner 1982). Imbrication and folding were coeval with the north directed emplacement of the Glarus nappe complex. To the south, the north-dipping Glarus overthrust and the reddish Verrucano in its hanging wall can be seen in the Wangs-Pizol area.

\section{Stop 3: Plaun Segnes Sut (Coord. 737'150/193'300)}

The eastern cliff of Plaun Segnes Sut exposes large-scale recumbent folds, mainly built up by Late Jurassic to Cretaceous rocks (see fig. 8 in Oberholzer 1933; fig. 2 in Bürgisser and Felder 1974; and fig. 6 in Pfiffner 1992). In this series, the inverted limb of an anticline is strongly tectonized, as shown by boudinage of the Mid-Cretaceous Garschella ('Gault') Formation. The Late Jurassic Quinten limestones of the Tschep nappe are intensely foliated parallel to the Tschep thrust (Calanda Phase feature). For more detailed information consult Bürgisser and Felder (1974) and Pfiffner (1992).

On the western side of Plaun Segnes Sut, the western continuation of these structures can be seen (Fig. 4; see also figs. 4 and 7 in Oberholzer 1933). Further to the north of the Tschep thrust, the Cenozoic of the Tschep nappe is separated from the Ultra-Helvetic Sardona Unit by a tectonic contact. All these 


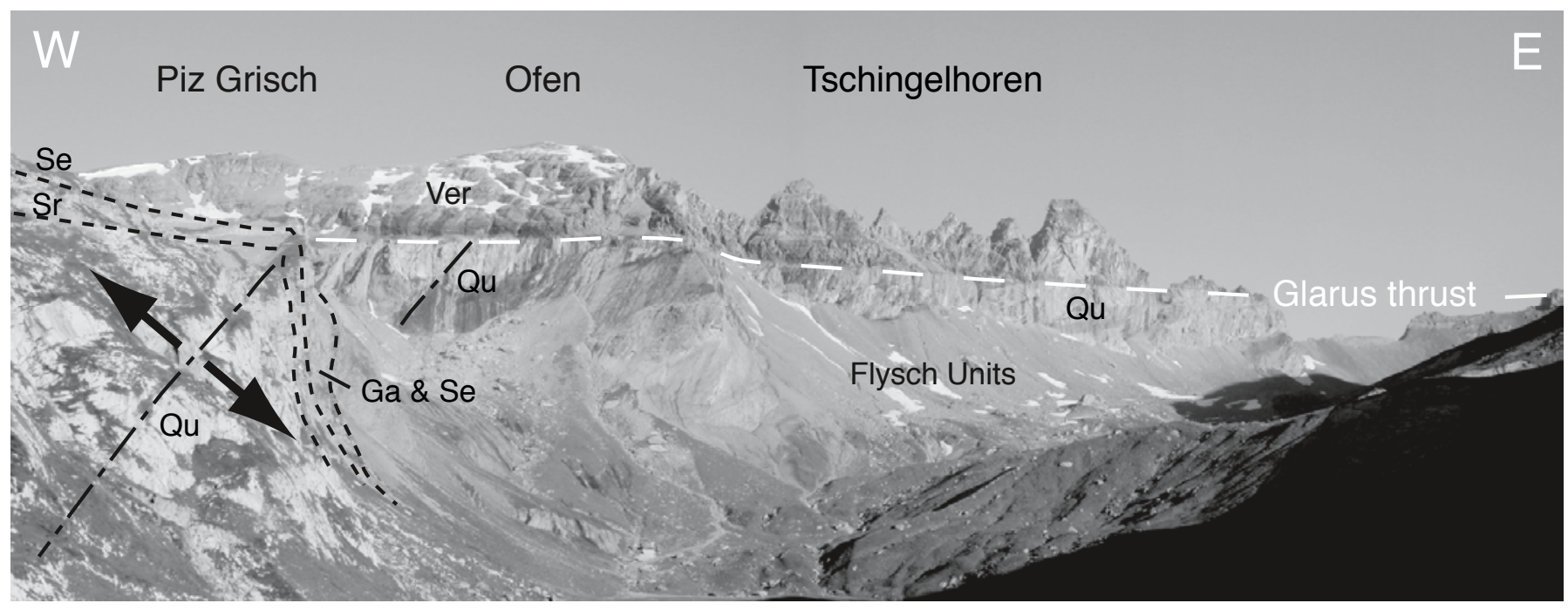

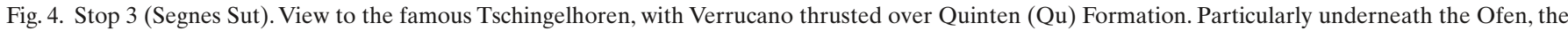

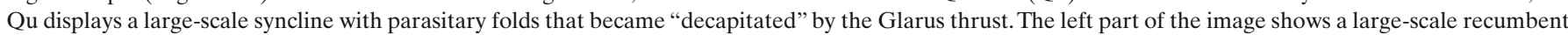

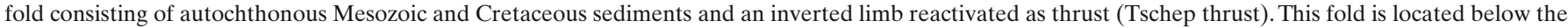
Glarus thrust and is characterized by an inverted limb mainly consisting of Schrattenkalk (Sr), Garschella (Ga) and Seewen (Se) Formation.

units, including the large-scale fold (Fig. 4), are truncated by the Glarus overthrust and were therefore finally overridden by the Verrucano at a later stage. North of the frontal fold of the Tschep nappe, in the area of the Ofen and the Tschingelhoren, imbricates of Schrattenkalk and Quinten Formation occur in the form of several $100 \mathrm{~m}$ long slices, sandwiched between the Verrucano of the hanging wall and the Sardona Flysch of the footwall (Fig. 4). These slices originate from more southern locations, where they were scraped off from Infrahelvetic slices, transported to their recent position, and then folded and decapitated again by the ongoing thrusting (see model depicted in Fig. 5). This implies that both top and bottom contacts of these slices must be of tectonic origin.

It is interesting to note that limestone - Flysch contacts have a cuspate-lobate geometry, while the limestone - Verrucano contacts are planar. Hence, we again see the same geometrical configuration previously reported from the Lochsite but this time on a much larger scale of several tens to hundreds of meters (see stop 1 and Fig. 2). Two hypotheses regarding the origin of this geometry can be postulated:

(1) As discussed above, the limestone slices were first affected by large-scale Calanda phase folding before being sheared off and accreted to the hanging wall Verrucano during a second phase, the Ruchi phase. Continuous overall simple shear, strongly localized near the Verrucano-limestone contact would lead to a planar contact, while the far weaker shearing in the lower parts of the detached limestones would have resulted in the formation of the cuspate-lobate structures at the Flysch-limestone interface (Fig. 2). Note that according to this hypothesis both contacts formed during ongoing Ruchi-phase deformation, post-dating the Calanda phase that formed the Tschep thrust and folds in its hanging wall (Pfiffner 1978, Funk et al.1983). In a rock mechanical point of view, the evolution of the cusps and lobes can be explained by a concentration of fluid flow in a thinner channel in the Lochsite tectonite just beneath the Verrucano. As a consequence, the deactivated older part further away from the Verrucano contact increases in strength owing to reduced pervasive fluid flow. Hence, the deactivated old mylonites become stronger than both the now active mylonites and Flysch, allowing the formation of the cuspate-lobate structures (see also discussion on HT and LT mylonites at stop 6). With continuous thrust-related shearing, deformation in the mylonites is further localized during retrograde conditions (see discussion below).

(2) According to a second and more complex post-Calanda phase scenario, which was proposed by Bas den Brok, Ruchi phase folding would have affected both Verrucano-limestone and Flysch-limestone interfaces in a first step, leading to the development of the steep cleavage visible in Fig. 4. This folding would then have been followed by a renewed out-of-sequence reactivation of the Glarus overthrust in form of a new planar thrust that crosscuts all the folds and brings the hanging wall further to the north. As a consequence, the hanging wall parts of the earlier formed Ruchi Phase folds should be found further to the north. Since they are now nowhere exposed, they could be located underneath the northern parts of the Helvetic thrust sheet below Walensee. In this alternative case, a post Ruchi phase displacement of more than $20 \mathrm{~km}$ would be required.

The regional-scale bending of the Glarus thrust, resulting in south- and north- dipping segments of the thrust plane with a culmination in the Segnespass area (see fig. 10 in Schmid 1975) was another point of discussion. S. Schmid interprets the curved geometry as being original and therefore thrustrelated, indicating steepening of the rearmost parts of the

328 M. Herwegh et al. 

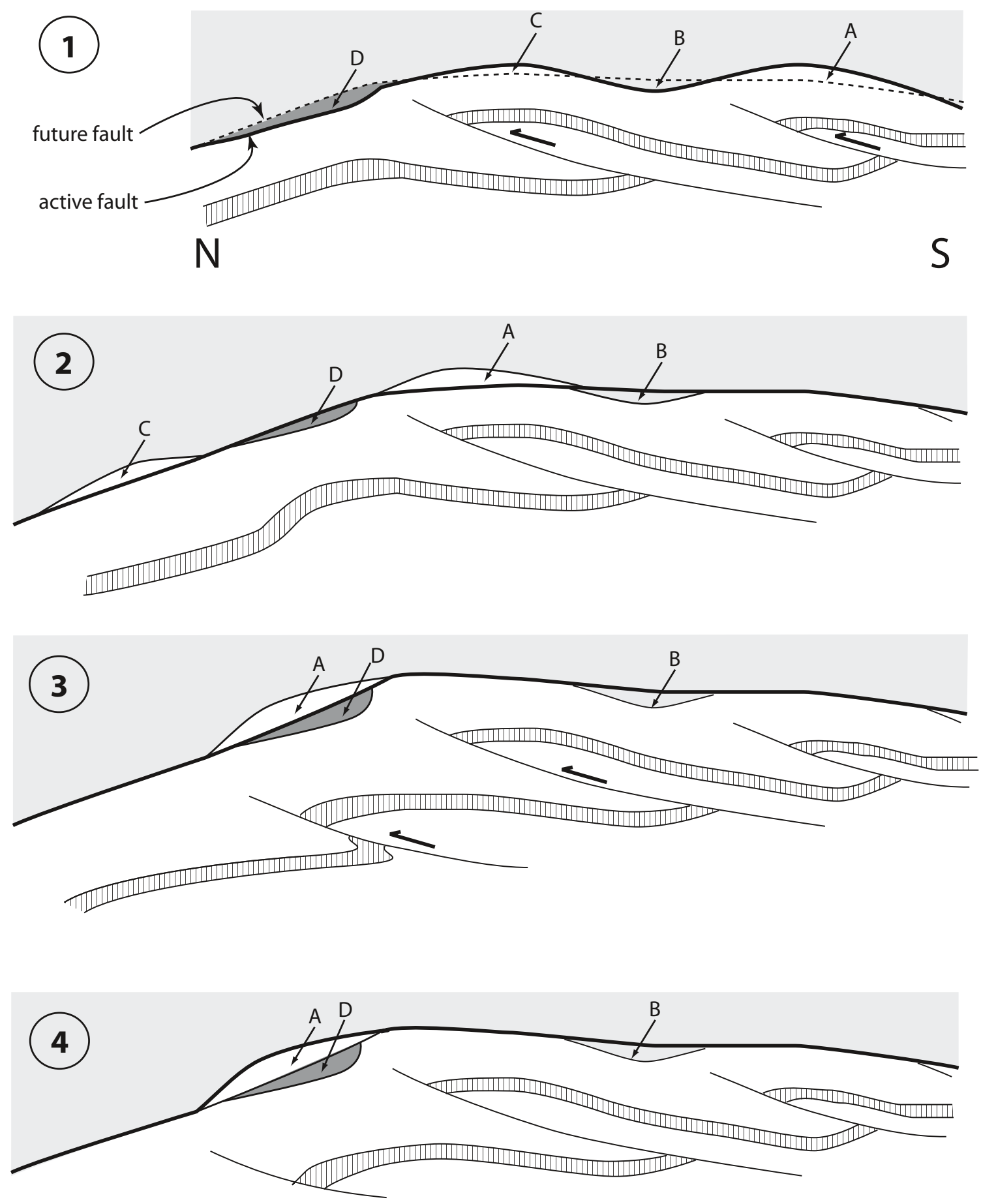

Fig. 5. Development of slices along the Glarus overthrust, schematically shown in 4 stages.

Stage 1: The major thrust fault is a ductile fault with contemporaneous deformation in the footwall (and hanging wall) during transport. Footwall deformation has already warped the major fault into an antiform. Undulations develop within the major thrust fault owing to local thrust faulting in the footwall and it becomes more and more difficult to accomplish motion along the major fault. Eventually a new thrust fault (dashed line) is developed that has a smoother surface. Stage 2: The new thrust fault has cut across the undulations and cut off four slices A, B, C and D. A and C are Mesozoic limestones. B is Verrucano, and D is exotic Flysch dragged along the major thrust.

Stage 3: Further deformation creates new undulations, giving the segment of the main fault between slices A and D an unfavorable orientation. As a consequence, the main fault uses the top of A as a new trace. C is displaced „out of sight“. Slice B (made of Verrucano and Lochsite tectonite) remains in the footwall of the major fault (similar to the situation observed at Foostock).

Stage 4: The main fault now moves the hanging wall rocks over slice A (Mesozoic limestone), comparable to the situation at Tschingelhoren. Slice D (exotic Flysch) remains in the footwall, as is the case for the Sardona and Blattengrat slices beneath Tschingelhoren. 

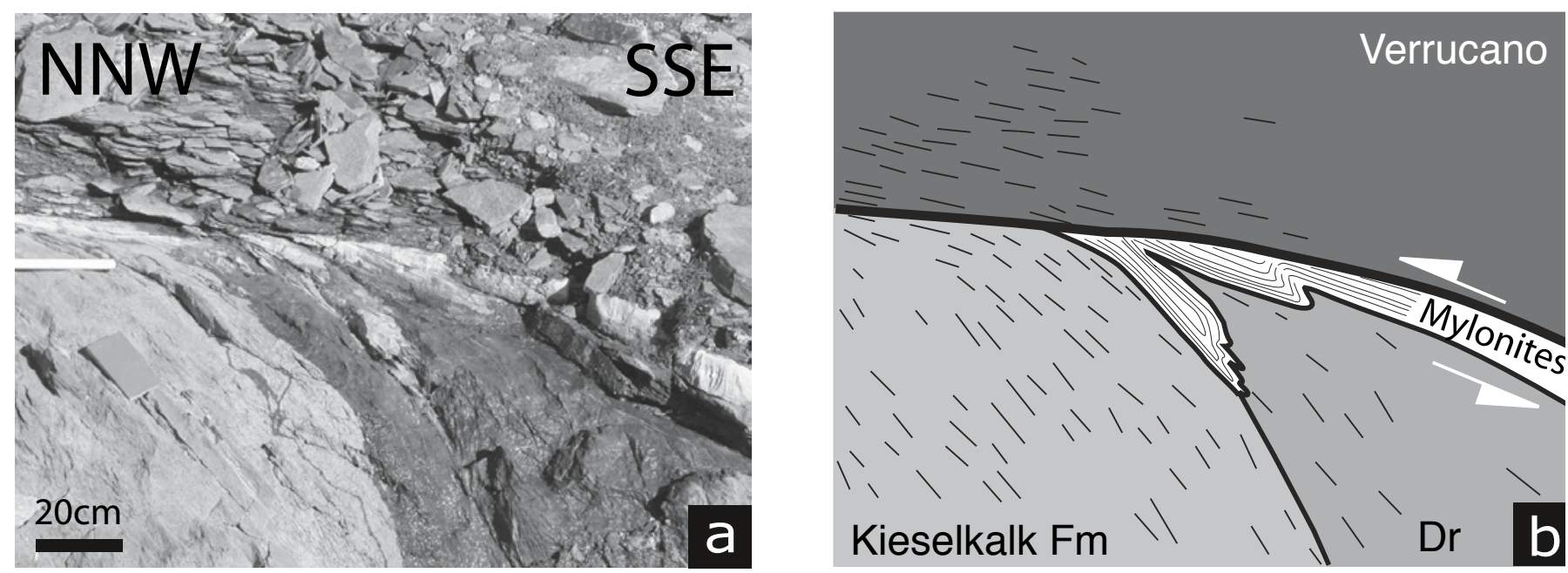

Fig. 6. Stop 5 (access road to Vorab). Kieselkalk Formation and Drusberg Formation (Dr) with internal Calanda Phase (early Ruchi Phase?) foliation, later sheared into parallelism with the Glarus thrust. Bright mylonites are folded, imbricated and also cut off at their contact with the Verrucano indicating an early HT mylonitization. This configuration was overprinted by more localized shearing along discrete faults during later retrograde deformation stages (LT deformation). Note that the apparent bending of the mylonites on the right side is due to perspective.

thrust plane. Later differential uplift in the south would have induced a large-scale passive rotation of the entire Glarus thrust plane. Rotations of about $7^{\circ}$ in the northern part of the Glarus overthrust were indeed suggested by apatite fission track studies performed by Rahn et al. (1997). As an alternative to the 'passive rotation model', Adrian Pfiffner proposes up-doming of the active Glarus overthrust as a consequence of shortening within the Infrahelvetic complex below (Fig. 5). In this concept, the Glarus thrust is behaving as a ductile fault, accommodating the displacement of the thrust faults developing in its footwall. The Glarus thrust is envisaged to extend southward down into the crystalline basement. Doming of the Aar massif in eastern Switzerland is kinematically linked to shortening in the Subalpine Molasse (Pfiffner 1986). In western Switzerland, the amplitude of up-doming is greater $(>10 \mathrm{~km})$ and is kinematically linked to shortening in Subalpine Molasse and Jura Mountains. In central and W-Switzerland the basal thrust was rotated more and was rotated passively in a later part of up-doming of the Aar massif (Grindelwald phase of Burkhard 1988). Since Jura mountain type structures are lacking in eastern Switzerland, Stefan Schmid advocates important along strike changes. Burkhard (1990) proposed a model, whereby oblique indentation involves clockwise rotation, resulting in varying shortening along strike. He proposed that it is rather thrusting within the Subalpine Molasse, rooting in the Internal massifs, which represents the final stages of Alpine compression in eastern Switzerland. This late deformation would be confined to areas structurally below the Glarus thrust and could have led a mere passive rotation of the Glarus thrust.

\section{September $15^{\text {th }} 2006$}

\section{Route}

Walk via ski slope from Segneshütte to Grauberg (2228 m), then to Camona da Nagens. Drive from Camona da Nagens to Vorab ski station (2670 m) and back to Flims (Fig. 1).

\section{Stop 4: Grauberg (Coord. 736'900/192'667)}

Deformed Zementstein Formation, which is part of the normal limb of the local fold in the Tschep nappe, is exposed along the uppermost part of the ski run coming down from Grauberg station (Fig. 1). This marly limestone shows different generations of calcite veins. Generally, the veins form at a high angle to the shear plane as tensile factures along which dilatancy occurs, allowing for the precipitation of dissolved calcite. As the veins rotate, flanking structures (Passchier 2001) evolve with progressive shearing. Veins either become folded when rotating into the compression field or become stretched and mylonitized when rotating into the extensional field. As the result of large shear strains, the veins rotated into parallelism with the Calanda phase foliation. Locally, a new and steeper foliation can be recognized, interpreted to represent a Ruchi phase structure.

\section{Stop 5: On the access road to Vorab (Coord. 734'700/192'500)}

A continuous stratigraphic sequence of Early Cretaceous limestones (Kieselkalk, Drusberg, and Schrattenkalk Formations), located below the Glarus overthrust, is intensely folded; it can be followed up to the immediate contact with the Verrucano (Figs. 1, 6 and 7). The fold axes trend E-W, with axial planes dipping $50-60^{\circ}$ to the south. The folds clearly represent par-

330 M. Herwegh et al. 

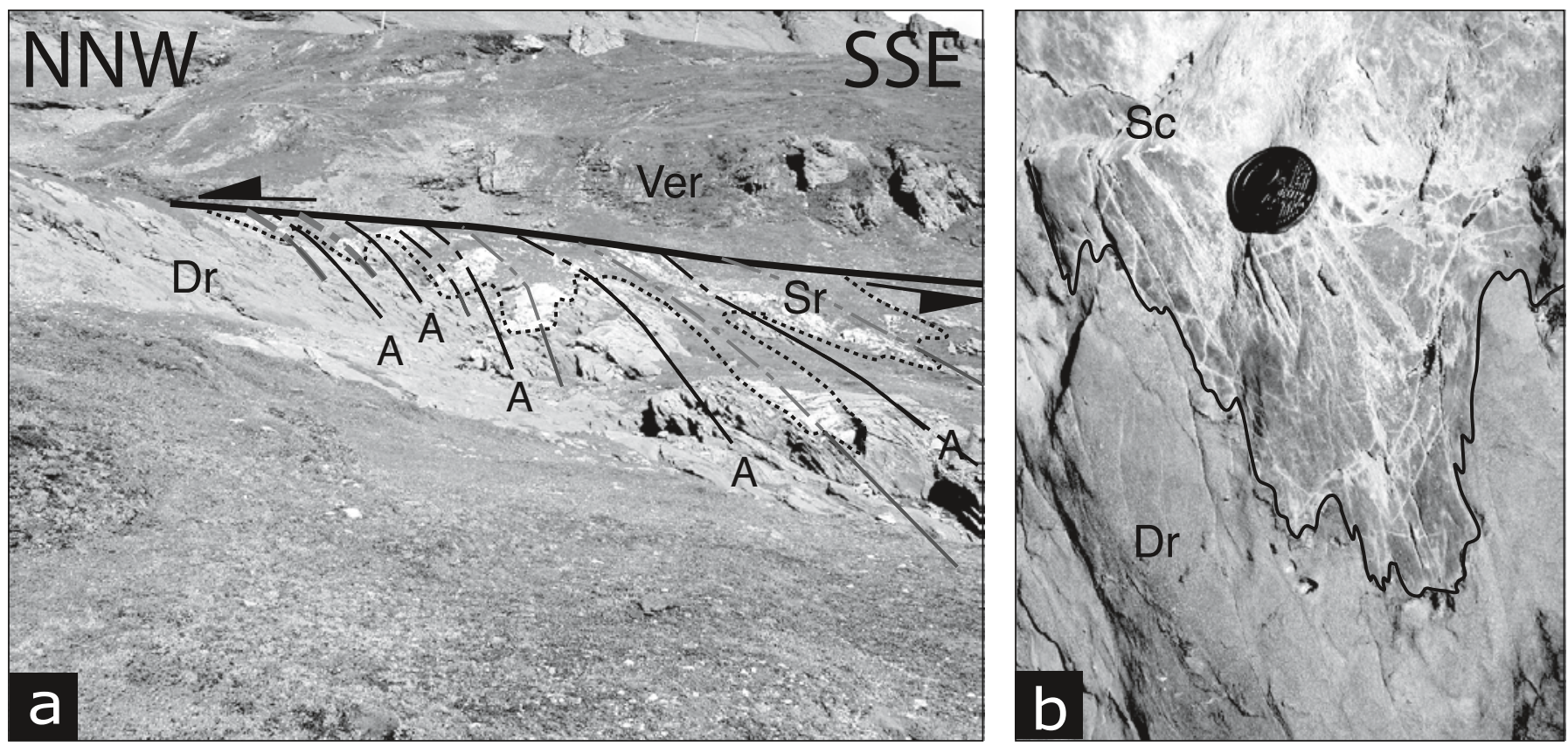

Fig. 7. Stop 5 (access road to Vorab). (a) Meso-scale folds in Schrattenkalk (Sr) and Drusberg (Dr) Formation, with (b) parasitic folds expressed at different scales (traces of axial planes of anticlines (A) and synclines). Note that the axial planes are sheared into the Glarus thrust, which "decapitates" the fold structures along a sharp plane.

asitic tight folds that occur at different scales, covering fold amplitudes from the $\mathrm{cm}$-scale up to $100 \mathrm{~m}$ (Fig. 7). This folding is associated with a penetrative axial planar cleavage that is characteristic for the Calanda phase. Ten meters below the thrust contact, an additional set of folds developed within the Drusberg Formation, with fold axes and axial planes of identical style and orientation to those found further down in the section. Some of the bedding interfaces, however, are irregularly shaped owing to paleo-karst. This karst was associated with Cretaceous tilting, as is demonstrated by local angular unconformities between the Drusberg and Schrattenkalk Formation. It is difficult to reconcile the preservation of this pre-deformational geometry with the high strains related to the Calanda phase deformation.

Due to the polymineralic character of the Drusberg beds, folded brownish seams of less soluble material show a higher relief compared to the weathered calcite layers. A debate arose as to whether these seams are of sedimentary origin, i.e. reflecting bedding or deformational origin during the Calanda phase. Thin section analysis revealed that these seams are indeed of sedimentary origin. This demonstrates that Calanda phase structures are preserved until at least $10 \mathrm{~m}$ below the Glarus thrust. Only at a distance of less than one meter below the thrust contact does the Calanda phase foliation of the footwall limestones bend into the shear plane, together with foliationparallel bands of calcite mylonites of a couple of centimeters thickness (Fig. 6). Parallel to the thrust contact, however, a 10$20 \mathrm{~cm}$ thick band of presumably later formed calcite mylonite is observed, characterized by a thrust parallel foliation. Hence, two generations of calcite mylonites apparently occur at this location, a point that will be discussed in more detail at stop 6 .

\section{Stop 6: Western outcrops of Vorab ski station (Coord. 732'350/192'650)}

Due to the enhanced melting of the Vorab glacier during the last couple of years, excellent new outcrops are now exposed. As a consequence of glacial erosion, the Glarus thrust and related deformation structures can be studied in three dimensions over an area of a couple of $100 \mathrm{~m}^{2}$. As already seen in previous outcrops, the deformation structures indicate that structures within and around the Lochsite tectonite formed during a long lasting and complex deformation sequence with different structural elements formed during specific deformation stages associated with thrusting (Fig. 8). The outcrops around the Vorab ski station provide an excellent insight into all these stages in terms of deformation fabrics and related geochemical changes (Figs. 8-11).

\subsection{Deformation fabrics}

Early high-temperature (HT) mylonites

The oldest structures occur at distances of 0.5 to $10 \mathrm{~m}$ away from the Verrucano contact, where the Lochsite tectonite is characterized by layers of mylonitized Schrattenkalk limestone, alternating with white calcite veins. These earlier mylonites are often folded (Fig. 8b). A mylonitic origin in the sense of high- 

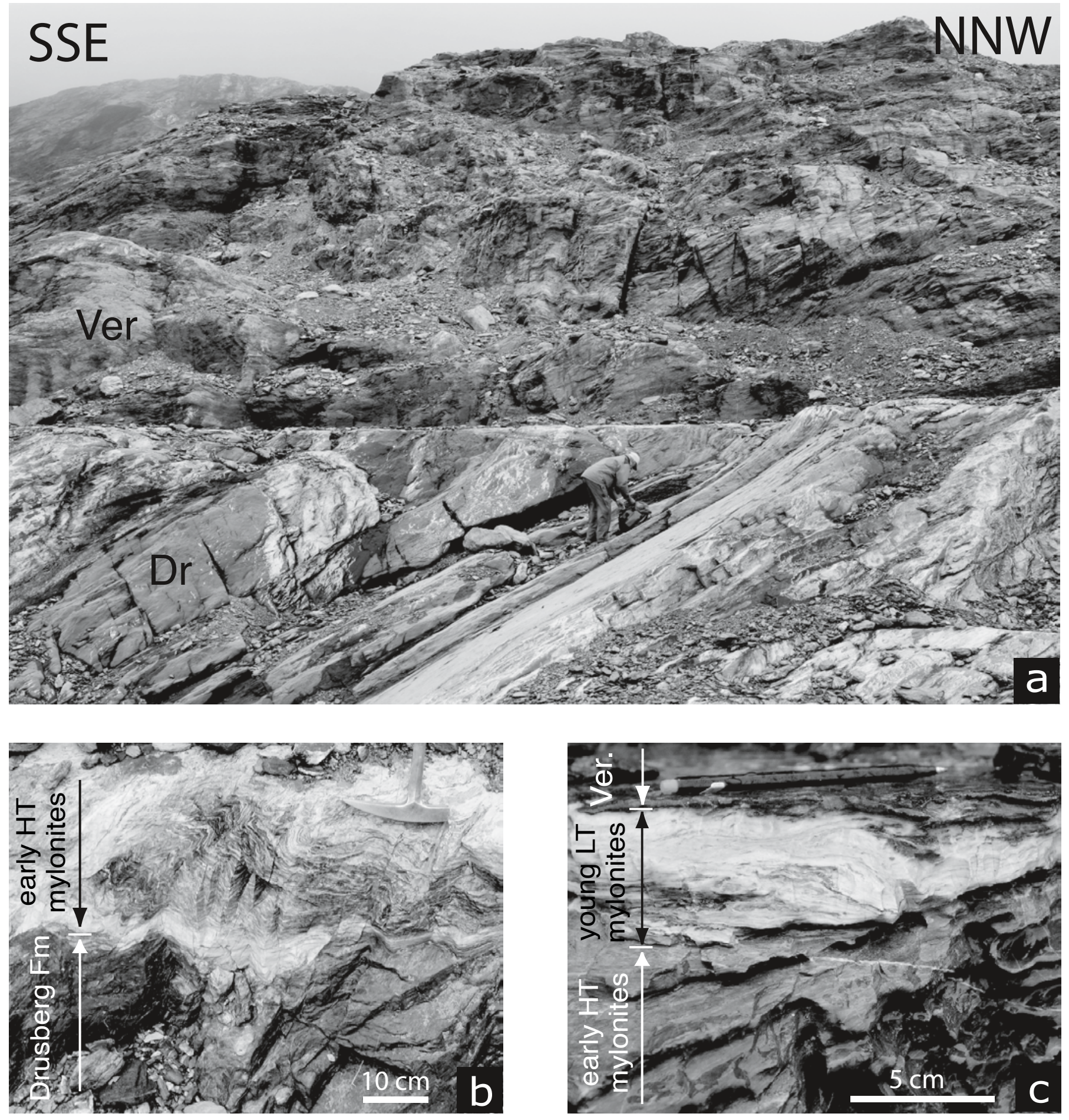

Fig. 8. Stop 6 (Vorab Pign). (a) Sharp boundary between footwall (Drusberg Formation, Dr) and hanging wall (Verrucano, Ver) of the Glarus thrust (photograph courtesy of Neil Mancktelow). (b) Early HT mylonites are characterized by intercalation of former vein calcite (white-yellowish) and grayish limestone. Note that these mylonites are folded. (c) Transition of early HT mylonites into the lighter colored LT mylonites. The latter are sub-parallel to the Verrucano contact and cut off the early HT mylonites.

strain viscous flow is supported by intense dynamic recrystallization, a dynamically stabilized recrystallized grain size and a strong crystallographic preferred orientation (CPO; e.g. Fig. 9. see also Ebert 2006, Ebert et al. 2007b). These features indicate that dislocation creep is the dominant deformation mechanism. However, intermittent cycles associated with brittle fracturing, 
calcite dissolution and vein formation are simultaneously active, as is indicated by the formation of calcite veins that were subsequently deformed. Hence, deformation is of a composite character and involves dislocation creep, as well as fracturing and mass transfer processes. This cyclic behavior is best explained in terms of pore pressure fluctuations, whereby periods of high fluid pressure induce fracturing and mass transfer processes. Since the recrystallized grain size is larger than that observed in the younger mylonites (see below), we infer higher temperatures during the formation of the early mylonites.

\section{Younger low-temperature (LT) mylonites}

The early mylonites described above are dissected by a white to yellowish part of the Lochsite tectonite about $10-20 \mathrm{~cm}$ below the Verrucano contact (Fig. 8c). This top part is not folded and shows a well-defined thrust parallel foliation. Again, a dynamically stabilized grain size formed; it is however, finer grained. The CPO's are weaker than those observed in the HT mylonites (see Fig. 9). Cycles of brittle fracturing, dilatancy, and calcite precipitation in the form of veins can again be found.

The comparison with the microfabric found in the older HT mylonites below suggests a transition in the dominant deformation mechanism, whereby the strain contribution of crystal plastic deformation (dislocation creep) decreased drastically. In the younger LT mylonites, different potential deformation processes were inferred from microstructural investigations (Ebert 2006, Ebert et al. 2007b): (a) dislocation creep assisted grain boundary sliding (superplasticity, Schmid et al. 1977, Pfiffner
1982); (b) granular flow, whereby the rotation of grains was accommodated at grain boundaries by a combination of dissolution-precipitation processes and grain boundary sliding and (c) cataclastic deformation. In the last case, an ultra-fine grained carbonaceous gouge (ultracataclasite) would have developed, with syn- to post-kinematic fluid circulation resulting in slight coarsening of the grains and their cementation after cataclasis.

However, there are several arguments that speak against the presence of cataclastic deformation:

1) The absence of a gradual transition from proto-cataclasite (with clasts from the host tectonite) via cataclasite into a potential ultra-cataclasite;

2) the gradual decay of both recrystallized grain size and CPO with increasing proximity towards the Verrucano contact.

3) At many locations, the small-sized calcite grains often are most intensely elongated, strongly twinned and show sutured grain boundaries, indicative for crystal plastic deformation in combination with a syn- to post-deformational grain boundary migration.

For these reasons, a cataclastic origin for the younger LT-tectonites seems unlikely, and we therefore advocate a mylonitic origin, favoring hypotheses (a) or (b) above. The term "superplasticity" was originally defined in metallurgy, i.e. for materials that deform under dry and hot conditions. Strain is mainly produced by the gliding of the grains along their boundaries. To overcome geometric strain compatibility problems along the grain boundaries, diffusion or dislocation creep processes are additionally required for allowing short-distance mass

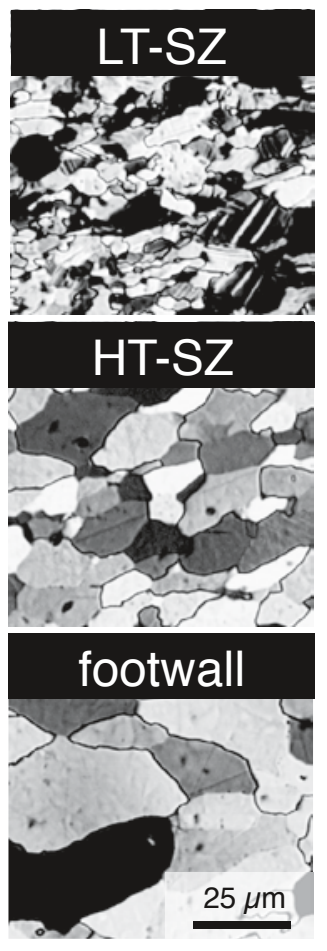

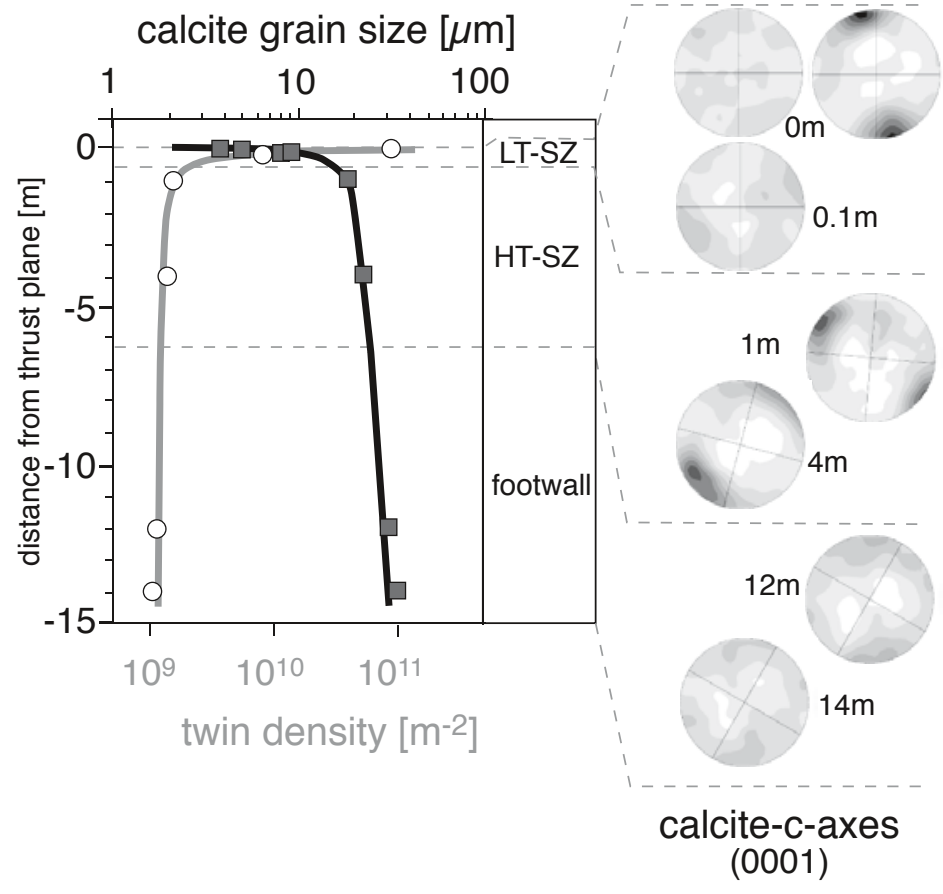

Fig. 9. Microfabric changes in a profile across the Glarus thrust (Cassons). Left column shows microfabrics characteristic for the footwall, the high (HT) and the retrograde low (LT) temperature shear zone (SZ). Note decreasing grain sizes and increasing twin density, respectively, towards the thrust contact $(0 \mathrm{~m})$. Crystallographic preferred orientations (CPO) are weak in the footwall, strong in the HT-SZ and weak and strong in the LT-SZ (right column, see text for explanations, data from Ebert 2006 and Ebert et al. 2007b).

The Glarus thrust 333 
transfer. Granular flow in the sense of Paterson (1995) comprises the same deformation processes, i.e. sliding and rotation of grains, but mass transfer involving a fluid phase plays a crucial role. Particularly material transfer from source to sinks is fundamental and can either be surface or transport controlled. Both superplasticity and granular flow involve negligible or no contributions of intracrystalline plasticity towards the deformation of the aggregate. In case of the Glarus thrust, the striking evidence for synkinematic fluid flow and the associated components of mass transfer recently motivated Ebert et al. (2007b) to favor the term 'granular flow' over the previously suggested term 'superplastic flow' (Schmid et al. 1977; Pfiffner 1982). On the other hand, S. Schmid proposed that one could also argue that mass transfer only occurred during intermittent cycles associated with brittle fracturing, induced by high pore pressure events.

\section{Late cataclastic structures}

Within the younger LT-mylonites, a late septum occurs in the form of brittle fractures, several meters to tens of meters long. Locally up to $2-3 \mathrm{~cm}$ thick polymict cataclasites can be observed along these fractures (see Fig. 7 in Ebert et al. 2007b). Although earlier cycles of brittle fracturing and vein formation were found to be active throughout the early history of thrusting within the calc-mylonites described above, such cycles have not been observed in the case of these polymict cataclasites, which therefore definitely formed later. We conclude that the formation of this type of cataclasite appears to be related to the latest increments of displacement along the Glarus thrust.

\section{Summary}

We conclude that the observations and interpretations summarized above all suggest that the deformation associated with the thrusting progressively changes with time from dominant crystal plasticity to dominant granular flow (or superplasticity). Thus, progressive deformation was accompanied by intermittent pore-pressure induced cycles of brittle fracturing and vein formation and finally by purely brittle deformation involving the formation of cataclasites. Major thrusting started under prograde to peak metamorphic conditions, whereas late stages of thrusting were clearly retrograde for the last $5-10 \mathrm{~km}$ of displacement along the Glarus thrust, as was postulated by Ebert et al. (2007b). Note that thrusting ranging from prograde till retrograde metamorphic conditions and associated changes in predominant deformation mechanisms were also reported for other thrust systems in the Helvetic Alps of central and western Switzerland indicating such deformation sequences to be of rather general character during deformation in mid crustal levels (Herwegh and Pfiffner 2005; Ebert et al. 2007a). In this progression, fluid flow played a fundamental role in case of the Glarus thrust during almost the entire deformation history, with local cycles of hydrofracturing and synkinematic vein formation occurring simultaneously with more distributed viscous deformation in the rest of the tectonite. Note that this model contrasts with the interpretation of Badertscher and Burkhard (2000), who rejected an evolution from crystal plastic to cataclastic deformation processes and instead suggested repeated changes from cataclastic to viscous deformation throughout the strain history. These authors also argue that the contribution of cataclastic deformation was relatively more important and hence that motion along the Glarus thrust may have been seismic. We argue, however, that structures indicating cataclastic deformation mechanisms only occur sporadically and are typically restricted to a few $\mathrm{dm}$ or $\mathrm{m}$ in the case of the Lochsite tectonite. This makes sliding by cataclastic processes over substantial portions of or along the entire length of the thrust at any given time interval rather unlikely.

\subsection{Stable isotope signature}

In contrast to the Lochsite locality (stop 1, Fig. 3), stable oxygen isotopes in calcite become depleted within the uppermost five meters of the footwall limestones (Fig. 10). When going towards the thrust contact (see also Badertscher et al. 2002) $\delta^{18} \mathrm{O}$ values decrease from 25-16\% in the Drusberg Member to 14\%o at the contact with the Verrucano. Within the Verrucano $\delta^{18} \mathrm{O}$ values as low as $12 \%$ are reached at about two meters above the thrust contact; this is about $4.5 \%$ ower compared to that measured in the Verrucano at the Lochsite locality.

\subsection{Geochemical alteration}

A narrow thrust-related alteration zone may be observed at the base of the Verrucano. In contrast to the northern locations, the alteration zone is macroscopically more difficult to distinguish from the higher unaltered parts of the Verrucano, because the color of the Verrucano remains green throughout. However, impregnation with carbonate phases is evident in the outcrop from the brownish weathering of ankerite-bearing carbonate veins and impregnations in the lowermost few decimeters of the Verrucano (Abart and Ramseyer 2002, Badertscher et al. 2002a $\& b)$. The Verrucano is chemically rather heterogeneous and it is difficult to discern rock alteration from background variability in bulk rock compositions. Nevertheless, systematic changes in the bulk rock compositions can be identified at the base of the Verrucano towards the contact with the Lochsite tectonite (Fig. 10). The most conspicuous feature is a pronounced depletion trend in $\mathrm{Na}_{2} \mathrm{O}$ and $\mathrm{Al}_{2} \mathrm{O}_{3}$ (Figs. 8 and 10). The $\mathrm{Al}_{2} \mathrm{O}_{3}$ contents decrease from background values in the range of about 15 to 20 wt. $\%$ down to 6 wt. $\%$ and the $\mathrm{Na}_{2} \mathrm{O}$ contents decrease from background values of about $4 \mathrm{wt}$ \% down to $0.2 \mathrm{wt}$ \% . At the same time the $\mathrm{CaO}$ contents show a pronounced increase from background values of about $3 \mathrm{wt}$. \% up to $15 \mathrm{wt} \%$ at the bottom of the Verrucano. These trends cannot be explained by passive dilution due to the infiltration of carbonate from below. Such a mechanism would imply constant element ratios amongst the alkali metals themselves, as well as between the alkali metals and the other immobile elements. Element ratios,

334 M. Herwegh et al. 


\section{Vorab Pign}

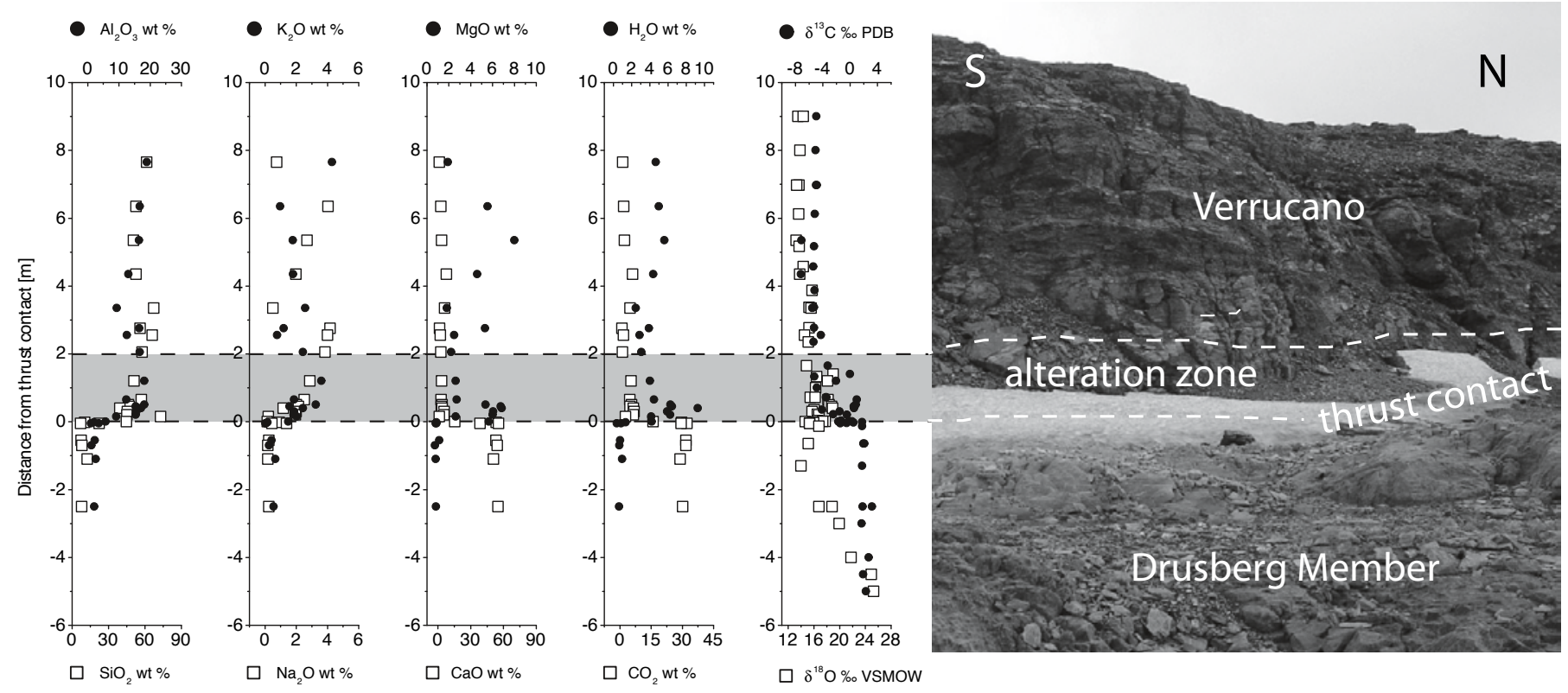

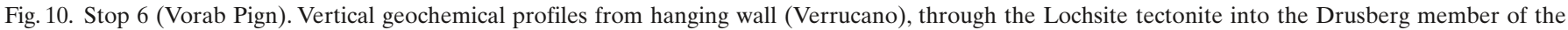
footwall. Zero position marks the Verrucano contact followed by its basal alteration zone (grey shading). Data from Hürzeler and Abart (2008).

however, vary substantially along the profiles. This indicates selective addition or removal of individual components. The decrease in sodium is readily explained by the dissolution of albite-rich plagioclase. This can, however, only explain part of the concomitant depletion in $\mathrm{Al}_{2} \mathrm{O}_{3}$. The remainder of the $\mathrm{Al}_{2} \mathrm{O}_{3}$ depletion is probably due to the disappearance of chlorite at the bottom of the Verrucano. $\mathrm{K}_{2} \mathrm{O}$ concentrations at the base of the Verrucano do not differ significantly from those in the unaltered portions further up. This indicates that potassium that was liberated from the dissolution of potassium feldspar, as is evident in thin section, was kept in place, due to the production of white mica. The increase in $\mathrm{CaO}$ content at the base of the Verrucano reflects carbonate impregnation and vein formation, whereby the most likely source of the carbonate is the underlying Cretaceous limestone.

On the whole, the alteration at the base of the Verrucano cannot be balanced locally with complementary alteration trends in the hanging wall and in the footwall. We propose a combination of two hypotheses to account for this observation. On the one hand, alteration at the base of the Verrucano may have started and largely occurred relatively early during thrusting, i.e. prior to a stage during which the Verrucano was juxtaposed over the footwall carbonates. On the other hand, mass transfer causing alteration probably occurred by thrust-parallel fluid flow; hence the sink for sodium and alumina has to be sought at a location further north, i.e. in the presumed direction of fluid flow. It is further proposed that thrust parallel fluid flow largely occurred in a cataclastic "damage zone" at the base of the Verrucano. Thus, fractures and fluids were possibly pres- ent throughout much of the thrusting activity, which suggests that alternating phases of cataclastic and crystal plastic creep have prevailed as Martin Burkhard had suggested. However, it seems hardly conceivable that the entire fluid flow was accommodated within the thin layer of Lochsite tectonite.

\subsection{Final interpretation of all available data regarding stop 6}

During the initial stages of the Glarus thrust a major shear zone with a width of no more than a few meters formed during peak metamorphic conditions. This stage is nowadays recorded by the early HT-mylonites (Figs. 8, 9 and 11). Due to the considerable temperature gradient, which prevailed form north $\left(\mathrm{c} .230^{\circ} \mathrm{C}\right)$ to south $\left(\mathrm{c} .350^{\circ} \mathrm{C}\right)$, shear zone width and dynamically stabilized grain sizes both increase towards the south (see Ebert et al. 2007b). Ongoing thrusting during exhumation by erosion resulted in an overall temperature decrease, which led to retrogression, but the N-S gradient was still preserved. As a consequence of reduced temperatures, deformation within the former high temperature shear zone further localized and this resulted in the formation of the younger LT mylonites (Figs. 8, 9 and 11). Grain size reduction and pore pressure induced events of brittle deformation were favored by reduced temperatures; this resulted in enhanced permeability and isotopic fractionation in the retrograde parts of the shear zone. Final deformation under purely brittle conditions induced the formation of brittle faults and locally cataclasites. The concept of a retrograde deformation style of the late LT mylonites, as well as the transition towards cataclastic structures, is compatible with the observation 


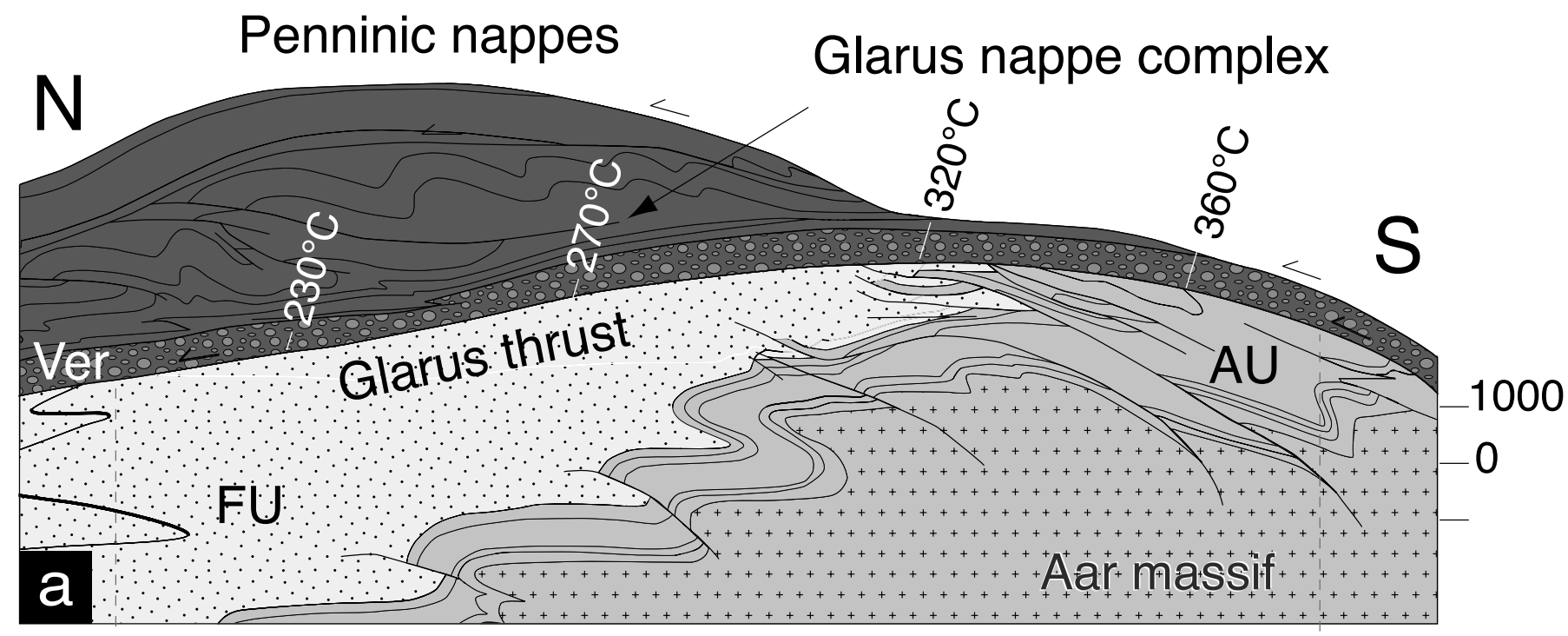

$10 \mathrm{~km}$
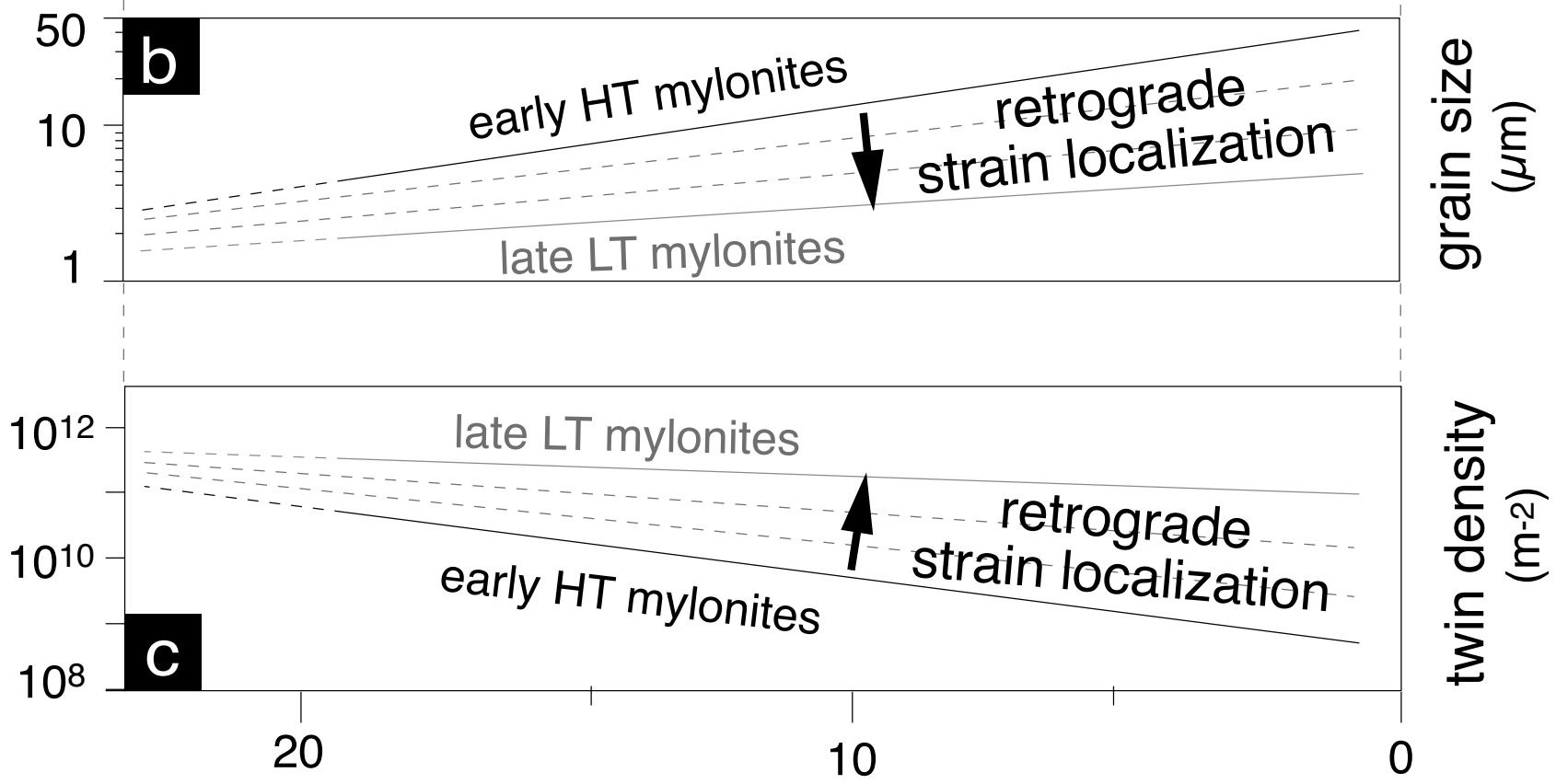

$\mathrm{N}$

distance along Glarus thrust $(\mathrm{km})$

Fig. 11. (a) Tectonic N-S profile modified after Pfiffner 1993 (AU: autochthonous Mesozoic sediments, FU: Flysch units, Ver: Verrucano, see Fig. 1 for profile trace). Temperatures indicate peak metamorphic conditions (after compilation of Ebert et al. 2007b). N-S gradients in grain size (b) and twin density (c) for HT and retrograde LT mylonites (based on data of Ebert 2006 and Ebert et al., 2007b).

that the peak-metamorphic isograds are offset along the Glarus thrust by some $10 \mathrm{~km}$ (Groshong et al. 1984; Frey 1988).

All this suggests that the calc-tectonites along the Glarus thrust record a transition from viscous (crystal plasticity and granular flow) to cataclastic deformation as the result of ongoing retrograde thrusting (see Ebert et al. 2007b). Fluid flow played a fundamental role during almost the entire deforma- tion history, but particularly during the latest stages. Local cycles of hydro-fracturing and synkinematic vein formation occurred contemporaneously with viscous deformation within the remaining part of the Lochsite tectonite. This contrasts with the interpretation of Badertscher and Burkhard (2000), who did not identify a systematic evolution from viscous to brittle deformation processes. Instead they suggested alternating 


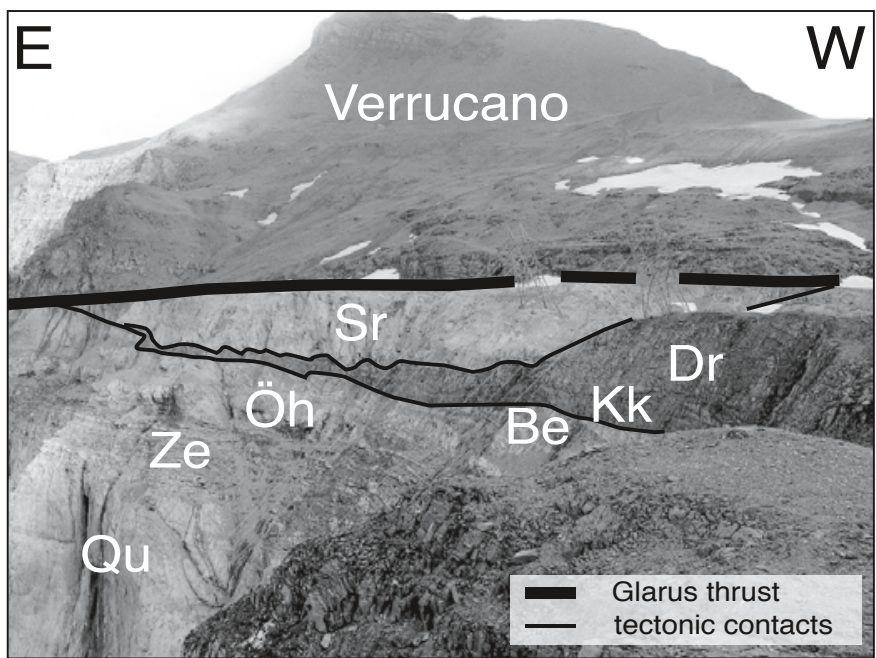

Fig. 12. Stop 7 (Bündner Bergjoch, view to the east to Laaxer Stöckli/Piz Grisch). Underneath the Glarus thrust, tectonic contacts between Schrattenkalk Formation (Sr) and Drusberg Formation (Dr) reflect the Formation of imbricates in the footwall of the Glarus thrust. Qu: Quinten Formation, Ze: Zementstein Formation, Öh: Öhrli Formation, Be: Betlis Formation, Kk: Kieselkalk Formation.

changes between ductile and cataclastic deformation throughout the strain history. Also, they possibly overemphasized the role of cataclastic processes. Brittle structures such as veins or faults are laterally restricted to a few $\mathrm{dm}$ to $\mathrm{m}$ in case of the Lochsite tectonite.

Considering fluid sources and fluid flux, stable isotope analyses clearly indicate that the Cretaceous limestones found in the footwall of the southern section of the thrust did not release fluid during thrusting. Hence, an upward directed flow component across the thrust may be ruled out in the south (Abart et al. 2002; Badertscher et al. 2002a). Chemical alteration at the base of the Verrucano in the southern section of the thrust rather suggests thrust-parallel fluid flow.

Note, however, that in the northern parts of the Glarus thrust the stable isotope profiles suggest a modest but widespread fluid supply from the footwall (see Abart et al. 2002). There the Flysch units in the footwall of the thrust clearly provide a potential fluid source. It is unclear yet whether these differences in fluid flux had mechanical implications during thrusting. However, as indicated by the synkinematic veins fluid must have been present during the entire period of thrusting.

\section{Stop 7: Bündner Bergjoch, Pass from Vorab to Elm above the Martinsmad Hütte (Coord. 733'090/193'830)}

Looking down the north-facing cliff provides a view into the footwall structures of the Infrahelvetic units of the Glarus nappe complex. While the lithologies directly below the Lochsite tectonite mainly consist of Mesozoic sediments (Drusberg Member and Schrattenkalk Formation) at this location, Cenozoic units above the Schrattenkalk, Wildflysch and Sar- dona Flysch are exposed further down the section. Internal imbrications within the Mesozoic sediments are manifest by local thrusts that dissect bedding (Figs. 11 and 12). A several hundred meter long limestone sheet, located underneath the Glarus thrust ca. $700 \mathrm{~m}$ west of Ofen $(2848 \mathrm{~m})$, is of special interest. Bas den Brok suggested that this sheet is isoclinally folded and may represent an olistolith embedded in the Wildflysch. If so, it would reflect a remnant of the very earliest movements along the Glarus overthrust, which evolved near the front of an accretionary prism, directly at the transition into the foreland basin. However, the authors favor the hypothesis that this slice represents the missing portions of the Mesozoic sediments, which were "decapitated" in an area such as that visited at Stop 6, where the Glarus thrust is seen to discordantly cut across the Calanda phase folds. This slice was scraped off by tectonic erosion and accreted to the footwall of the Verrucano in the area of the Tschingelhoren (and possibly further north at the Foostock, see Stop Nr. 8) during progressive northwards thrusting.

\section{September 16 ${ }^{\text {th }} 2006$}

\section{Route}

Drive from Flims into Weisstannental (SG), up to Alp Untersäss. Then walk 2.5-3 hrs via Alp Foo to the southern cliff of the Foostock and back (2 hrs) to Alp Untersäss. Drive from Alp Untersäss back to Ziegelbrücke (Fig. 1).

\section{Stop 8: Near Rossalphüttli (Coord. 738'078/201'235)}

Walking from Alp Untersäss to Alp Foo, different Flysch units (Rüefli 1959; see also Bisig 1957; Wegmann 1961) are crossed in the following order: (1) The South Helvetic Blattengrat Unit, consisting of Late Cretaceous Amdener Marls, Globigerina Marls (Stad Formation), Eocene Nummulitic limestones (Bürgen Formation), and Late Eocene (to Oligocene?) Globigerina Marl; (2) The North Penninic Sardona Unit, including the so-called 'Infraquartzite Flysch' (Lihou 1996). A view to the N-NW from Rossalphüttli reveals the internal structure of Foostock (Fig. 13a). The upper part of this south-dipping cliff mainly consists of Verrucano. At the base of the Verrucano cliff, a limestone slice (probably Schrattenkalk Formation) of several tens of meters thickness can be observed. The tectonic contact at the base probably indicates that this slice was torn off somewhere in the south ("decapitation" of Calanda phase structures, see stop 7 and Fig. 5) and then transported a long distance $(>10 \mathrm{~km})$ towards the north during thrusting. The thickness of the slice decreases rapidly towards the W (location of the next stop). Beneath this limestone slice, a layer of Wildflysch overlies the Sardona Unit. Note that tectonic contacts between Sardona Unit and Wildflysch, and between Wildflysch and Lochsite tectonite, are folded. The only feature not affected by the folding are the younger LT-mylonites that occur in a $10-20 \mathrm{~cm}$ thick layer directly beneath the Verrucano, 

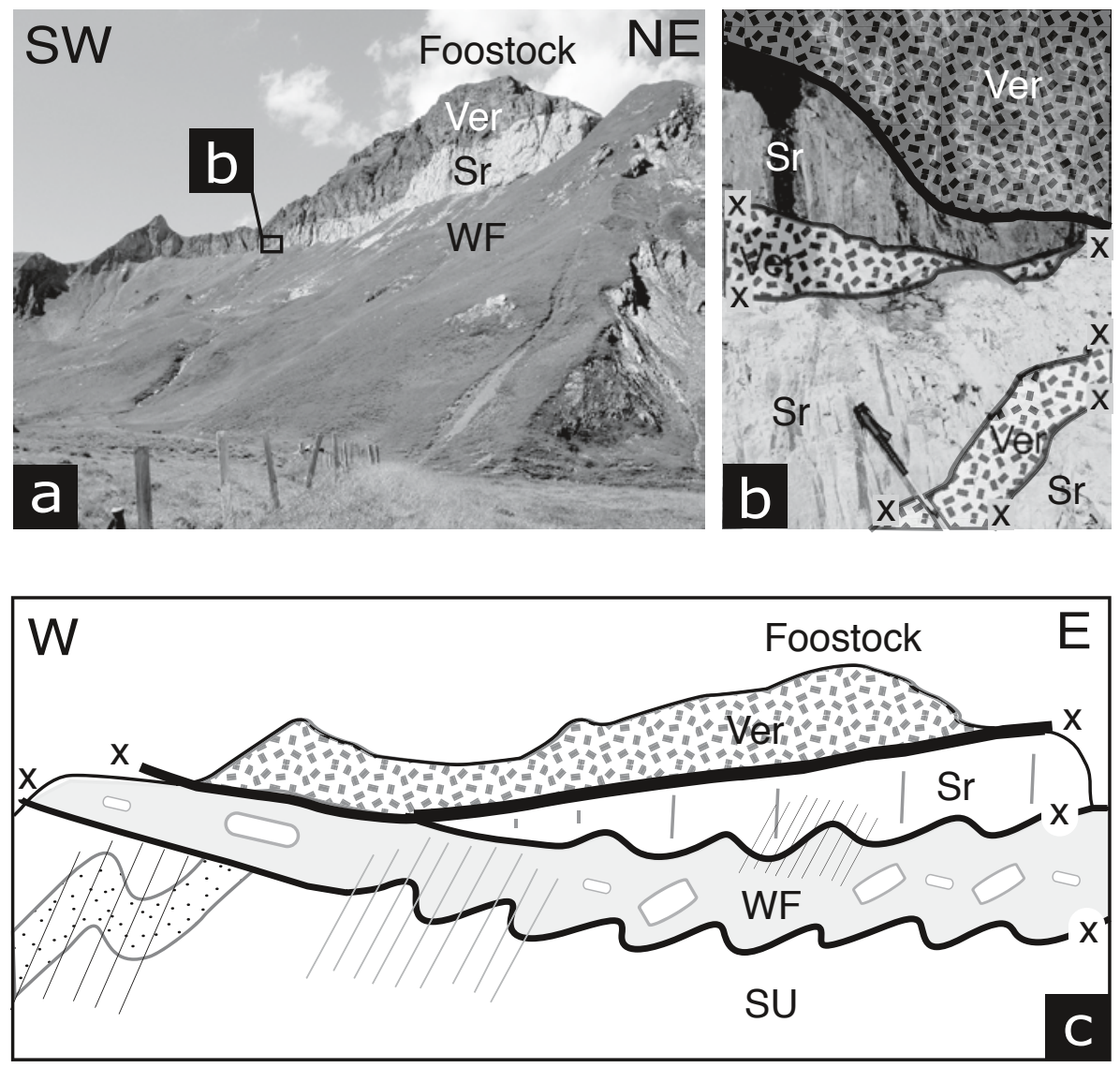

Fig. 13. Stop 8 (Foostock). (a) South face of the Foostock shows a several hundred meters long limestone slice (probably Schrattenkalk Formation, $\mathrm{Sr}$ ) that is tectonically sandwiched between Wildflysch (WF) and Verrucano (Ver) in the footand hanging wall, respectively. (b) The $\mathrm{W}$ end of the slice shows on the outcrop-scale a deformation-induced intercalation of several meter long and up to $1.5 \mathrm{~m}$ thick slices of Schrattenkalk and Verrucano. (c) Schematic drawing of the complex tectonic situation at the Foostock (slightly modified after field-sketch by Bas den Brok), where several cycles of thrusting followed by folding and the formation of steep foliations resulted in the large-scale imbrication of Sardona Unit (SU), Wildflysch, Schrattenkalk formation and Verrucano. Note that all tectonic contacts are folded except the Sr-Ver contact comprising the late LT mylonites.

which show a thrust parallel foliation, similar to the situation described at stop 6 (Fig. 8b).

In summary, the present geometry documents a deformation sequence that involves thrusting and folding. A discussion arose as to whether this sequence resulted from an ongoing progressive deformation, or alternatively, as the result of rather distinct folding and thrusting events, possibly even with time gaps and or erosional events in between them as is the case in the hypothesis of a "Reliefüberschiebung" proposed by Bas den Brok. It is evident that meso-scale folds observed in the footwall are again cut ("decapitated") by the Glarus thrust. The cut-off counterparts should nowadays be found further north, in an area that is not exposed owing to the $\mathrm{N}$ dip of the Glarus thrust.

Bas den Brock explained this lack of allochthonous slices, as well as the fact that the Glarus thrust cut away substantial volumes of rocks from the footwall, by the existence of an erosional phase that prevailed between the folding of the early mylonites and the formation of the younger thrust-parallel mylonites. Erosion is thought to have removed the missing volume of rocks. Detritus from the Austroalpine and Penninic nappes, however, dominates the pebble spectra in the Molasse basin further north.

Alternatively, Stefan Schmid proposed a continuous deformation sequence without considerable time gaps but a progres- sive thrusting involving the "decapitation" of substantial rock volumes (tectonic erosion), their northward transport and their accretion to the overlying Verrucano further north. Finally, Pfiffner explained the origin of the slices by the Glarus thrust smoothing out undulations as demonstrated in Fig. 5.

It was agreed that the truncation of the Calanda phase structures (including folded former tectonic contacts between the different Flysch nappes) beneath the Glarus thrust in a geometrical sense, led to the incredibly sharp planar contact of the Glarus thrust (see Fig. 8).

\section{Stop 9: Foostock south face (Coord. 737'221/202'020)}

The outcrops at this locality present meso-scale details of the structures formed at the contacts between limestone slices and Wildflysch, as well as those between and limestone slices and Verrucano (Fig. 13). The contact between the limestone slice and the Wildflysch exposes foliated layers of grayish limestone and white calcite veins that are folded. Their appearance is very similar to the early generation of the Lochsite tectonite described above. At its western end, the thickness of the limestone layer rapidly decreases (see previous stop). At the contact between Verrucano and limestone a multiple repetition of 0.5 to 2 meter thick slices of Verrucano and limestone may be observed (Fig. 13b). This is probably the result of a local distur-

338 M. Herwegh et al. 
bance caused by an irregularity in the initial slice of the Glarus thrust, which was evened out by progressively cutting off slices from undulations in the thrust surface (see Fig. 5).

The view to the south provides a summary of the features seen throughout the excursion. The large-scale dome-shaped geometry of the Glarus thrust is visible over a distance of several kilometers. The thrust plane culminates in the SW at the outcrops at Vorab (Stop 7), visited the previous day. Towards the $\mathrm{E}$, the culmination first climbs to an elevation of about $3100 \mathrm{~m}$ in the Ringelspitz region, and than drops with an axial plunge of $30^{\circ}$ rather abruptly towards the E underneath the Seez valley.

\section{Acknowledgements}

The authors would like to thank all the participants of the STSG excursion 2006 for their stimulating discussions, which provided an important contribution to the success of the excursion. The reviews provided by Neil Mancktelow and Bas den Brok are gratefully acknowledged. Financial support by the Swiss Science National Foundations is acknowledged by both the Bernese (SNF grants 21-66889.01 and 200020-103720) and Basel (SNF grant 200020111860/1) research groups.

\section{REFERENCES}

Abart R., \& Ramseyer K. 2002: Deformation induced quartz-fluid oxygen isotope exchange during low-grade metamorphism: an example from the Glarus thrust, E Switzerland. Schweizerische Mineralogische und Petrographische Mitteilungen 82, 291-302.

Abart, R., Badertscher, N.P, Burkhard, M. \& Povoden, E. 2002: Oxygen, carbon and strontium isotope systematics in two profiles across the Glarus thrust: implications for fluid flow. Contributions to Mineralogy and Petrology 143, 192-208

Badertscher, N.P., Abart, R., Burkhard, M. \& McCaig, A. 2002a: Fluid flow pathways along the Glarus overthrust derived from stable and Sr-isotope patterns. American Journal of Science 302, 517-547.

Badertscher, N.P., Beaudoin, G., Therrin, R. \& Burkhard, M. 2002b: Glarus overthrust: A major pathway for the escape of fluids out of the Alpine orogen. Geology 30, 875-878.

Badertscher, N.P. \& Burkhard, M. 2000: Brittle-ductile deformation in the Glarus Lochsite (LK) calc-mylonite. Terra Nova 12, 281-288.

Bertrand, M. 1884: Raport de structure des Alps de Glaris et du bassin huiller du Nord. Bulletin de la Société Géologique de France 12,318-330.

Bisig, W.K. 1957: Blattengratflysch und Sardonaflysch im Sernftal nördlich der Linie Richetlipass - Elm - Ramintal - Grosse Scheibe. Diss. Nr. 2435, ETH Zürich, 239 pp. (Mitteilungen des geologischen Institutes der ETH und der Universität Zürich; C74).

Briegel, U. \& Goetze, C. 1978: Estimates of differential stress recorded in the dislocation structure of Lochseiten Limestone (Switzerland). Tectonophysics 48, 61-76.

Bürgisser, H.M. \& Felder, T.E. 1974: Geologie der Südabdachung der SegnasRingel-Gruppe. Eclogae Geologicae Helvetiae 67, 457-467.

Burkhard, M. 1988: L'Helvetique de la bordure occidentale du massif de l'Aar (évolution tectonique et métamorphique). Eclogae Geologicae Helvetiae 81, 63-114.

Burkhard, M. 1990: Aspects of the large-scale Miocene deformation in the most external part of the Swiss Alps (Subalpine Molasse to Jura fold belt). In: Jordan, P., Noack, Th., Schmid, S.M. \& Bernoulli, D. (Eds) The Hans Laubscher Volume. Eclogae Geologicae Helvetiae, Basel, Birkhaeuser Verlag 83, 559-583.

Burkhard, M., Kerrich, R., Maas, R. \& Fyfe, W.S. 1992: Stable and Sr-isotope evidence for fluid advection during thrusting of the Glarus nappe (Swiss Alps). Contributions to Mineralogy and Petrology 112, 293-311.
Ebert, A. 2006: Microfabric evolution in pure and impure carbonate mylonites and their role for strain localization in large-scale shear zones. Unpublished $\mathrm{PhD}$ thesis, University of Bern.

Ebert A., Herwegh, M., Austin, N., Evans, B., Pfiffner, O.A. 2007a: Microfabrics in carbonate mylonites along a large-scale shear zone (Helvetic Alps). Tectonophysics 444, 1-26.

Ebert, A., Herwegh, M. \& Pfiffner, O.A. 2007b: Cooling induced strain localization in carbonate mylonites within a large-scale shear zone (Glarus thrust, Switzerland). Journal of Structural Geology 29,1164-1184.

Funk, H., Labhart, T.P., Milnes, A.G., Pfiffner, O.A., Schaltegger, U., Schindler, C., Schmid, S.M., Trümpy, R. 1983: Report on the excursion of the jubilee of the Swiss Geological Society from 12 to 17 September 1982, east and center of the Swiss Helvetikum and northern Aar Massif on the mechanism of formation of mountains. Eclogae Geologicae Helvetiae 76, 91-123.

Frey, M. 1988: Discontinuous inverse metamorphic zonation, Glarus Alps, Switzerland; evidence from illite crystallinity data. Schweizerische Mineralogische und Petrographische Mitteilungen 68,171-183.

Gasser, D. 2006: Vom Meeresboden auf das Hausdach - tektonische Entwicklung der Engi-Dachschiefer. Unpublished diploma thesis ETH Zürich, $125 \mathrm{pp}$.

Gasser D., \& den Brok, B. (2008): Tectonic evolution of the Engi Slates, Glarus Alps, Switzerland. Swiss Journal of Geosciences. 101, 311-322.

Giger, S., 2003: Structure and deformation mechanisms of the Lochseiten limestone along the Glarus overthrust. Diplomarbeit ETH Zürich, 97 pp. (incl. structural map 1:10,000 of Kärpf-area with special emphasis on the Glarus overthrust).

Groshong, R.H., Pfiffner, O.A. \& Pringle, L.R. 1984: Strain partitioning in the Helvetic thrust belt of eastern Switzerland from the leading edge to the internal zone. In: Hancock, P.L., Klaper, E.M., Mancktelow, N.S. \& Ramsay, J.G. (Eds). Planar and linear fabrics of deformed rocks; a selection of papers delivered at an international conference held at ETH. Journal of Structural Geology 6, 5-18.

Groshong, R. 1988: Low-temperature deformation mechanisms and their interpretation. Geological Society of America Bulletin 100,1329-1360.

Heim, A. 1878: Untersuchungen über den Mechanismus der Gebrigsbildung im Anschluss an die geologische Monographie der Tödi-WindgällenGruppe. Schwabe, Basel.

Heim, A. 1921: Geologie der Schweiz. Band 2: Die Schweizer Alpen. Tauchniz, Leipzig.

Heim, A. 1929: An der Erkenntniswurzel alpiner Tektonik. Vierteljahrschrift der naturforschenden Gesellschaft in Zürich 74, 213-233.

Helbling, R. 1948: Photogeologische Karte der Tödikette vom Bifertenstock bis Calanda. Orell Füssli, Zürich.

Herwegh, M., \& Pfiffner, O.A. 2005: Tectono-metamorphic evolution of a nappe stack: A case study of the Swiss Alps, Tectonophysics 404, 55-76.

Hsü, K. 1969: A preliminary analysis of the statistics and kinematics of the Glarus overthrust. Eclogae Geologicae Helvetiae 62, 143-154.

Hunziker, J.C., Frey, M., Caluer, N., Dallmeyer, R.D., Friedrichsen, H., Flehmig, W., Hochstrasser, K., Roggwiler, P. \& Schwander, H. 1986: The evolution of illite to muscovite; mineralogical and isotopic data from the Glarus Alps, Switzerland. Contributions to Mineralogy and Petrology $92,157-180$.

Hürzeler, J.-P. \& Abart, R. (2008): Fluid flow and rock alteration along the Glarus Thrust. Swiss Journal of Geosciences. 101, 251-268.

Jagoutz, O., 2000: Description of the deformation structures in the hanging and footwall of the Glarus thrust. Unpublished Diploma thesis Johannes Gutenberg Universität Mainz/ETH Zürich.

Lihou, J.C. 1996: Stratigraphy and sedimentology of the Sardona unit, Glarus Alps: Upper Cretaceous/middle Eocene deep-marine flysch sediments from the Ultrahelvetic realm. Eclogae Geologicae Helvetiae 89, 721752.

Milnes, A.G. \& Pfiffner, O.A. 1977: Structural development of the Infrahelvetic Complex, eastern Switzerland. Eclogae Geologicae Helvetiae 70, $83-95$.

Mullis, J., Rahn, M.K., Schwer, P., de Capitani, Ch., Stern, W.B. \& Frey, M. 2002: Correlation of fluid inclusion temperatures with illite crystallinity data and clay mineral chemistry in sedimentary rocks from the external part 
of the Central Alps. Schweizerische Mineralogische und Petrographische Mitteilungen 82,325-340.

Oberholzer, J. 1933: Geologie der Glarner Alpen. Beitrag zur geologischen Karte der Schweiz Bern [N.F.] 28.

Passchier, C.W. 2001: Flanking structures. Journal of Structural Geology 23 , 951-962.

Paterson, M. 1995: A theory of granular flow accommodated by material transfer via intergranular fluid. Tectonophysics $245,135-151$.

Pfiffner, O.A. 1977:Tektonische Untersuchungen im Infrahelvetikum der Ostschweiz. Mitteilungen des geolologischen Instituts der ETH und Universität Zürich 217.

Pfiffner, O.A. 1978: Der Falten- und Kleindeckenbau im Infrahelvetikum der Ostschweiz. Eclogae Geologicae Helvetiae 71, 61-84.

Pfiffner, O.A. 1980: Strain analysis in folds (Infrahelvetic Complex, Central Alps). Tectonophysics 61, 337-362.

Pfiffner, O.A. 1982: Deformation mechanisms and flow regimes in limestone from the Helvetic zone of the Swiss Alps. Journal of Structural Geology $4,429-442$.

Pfiffner, O.A. 1986: Evolution of the North Alpine foreland basin in the Central Alps. In: Allen, P. \& Homewood, P. (Eds): Foreland Basins. Special Publication of the International Association of Sedimentologists. Blackwell, Oxford, 219-228.

Pfiffner, O.A. 1992: Zur Tektonik des Helvetikums im Querschnitt der Ostschweiz. Eclogae Geologicae Helvetiae 85, 235-244.

Pfiffner, O.A. 1993: The structure of the Helvetic nappes and its relation to the mechanical stratigraphy. Journal of Structural Geology 15, 511521.

Rahn, M., Mullis, J., Erdelbrock, K. \& Frey, M. 1994: Very Low-Grade Metamorphism of the Taveyanne Greywacke, Glarus Alps, Switzerland. Journal of Metamorphic Geology 12, 625-641.

Rahn, M., Mullis, J., Erdelbrock, K. \& Frey, M. 1995: Alpine metamorphism in the North Helvetic Flysch of the Glarus Alps, Switzerland. Eclogae Geologicae Helvetiae 88, 157-178.

Rahn, M.K., Hurford, T. \& Mullis, J. 1997: Rotation and exhumation of a thrust plane: Apatite fission track data from the Glarus thrust, Switzerland. Geology 25, 599-602.

Ring, U., Brandon, M. T. \& Ramthun, A. 2001: Solution-mass-transfer deformation adjacent to the Glarus Thrust, with implications for the tectonic evolution of the Alpine wedge in eastern Switzerland. Journal of Structural Geology 23,1491-1505.
Rüefli, W.H. 1959: Stratigraphie und Tektonik des Eingeschlossenen Glarner Flysches im Weisstannental (St. Galler Oberland). Diss Nr. 2780 ETH Zürich, $194 \mathrm{pp}$.

Schmid, S.M. 1975: The Glarus overthrust; field evidence and mechanical model. Eclogae Geologicae Helvetiae 68, 247-280.

Schmid, S.M. 1976: Rheological evidence for changes in the deformation mechanism of Solnhofen limestone towards low stresses. Tectonophysics 31, T21-T28.

Schmid, S.M. 1981: Laboratory experiments on rheology and deformation mechanisms in calcite rocks and their application to studies in the field. Mitteilungen aus dem Geologischen Insitut der ETH und der Universität Zürich N.F. 241, 106 pp.

Schmid, S.M. 1982: Microfabric Studies as Indicators of deformation Mechanisms and Flow Laws operative in Mountain Building. Mountain Building Processes. K. J. Hsü. London, Academic Press, 95-110.

Schmid, S.M. \& Handy, M.R. 1991: Towards a genetic classification of fault rocks: geological usage and tectonophysical implications. Controversies in Modern Geology. (D.W.Müller, J.A.McKenzie \& H.Weissert, editors). Academic Press, 95-110.

Schmid, S.M., Boland, J.N. \& Paterson, M.S. 1977: Superplastic flow in finegrained limestone. Tectonophysics 43, 257-291.

Siddans, A.W.B. 1979: Deformation, metamorphism and texture development in Permian mudstones of the Glarus Alps (eastern Switzerland). Eclogae Geologicae Helvetiae 72, 601-621.

Staub, R. 1954: Der Bau der Glarneralpen und seine prinzipielle Bedeutung für die Alpengeologie. Tschudi, Glarus.

Trümpy, R. 1991: The Glarus nappes; a controversy of a century ago. In: Controversies in Modern Geology (D.W.Müller, J.A.McKenzie \& H.Weissert, editors) Academic Press, 385-404.

Trümpy, R.1969:Die helvetischen Decken der Ostschweiz:Versuch einer palinspastischen Korrelation und Ansätze zu einer kinematischen Analyse. Eclogae Geologicae Helvetiae 62, 105-142.

Wegmann, R. 1961: Zur Geologie der Flyschgebiete südlich Elm (Kt. Glarus). Diss Universität Zürich.

Manuscript received November 7, 2007

Revision accepted January 30, 2008

Published Online first July 31, 2008

Editorial Handling: Neil Mancktelow 